\title{
Breast Cancer Metabolomics: From Analytical Platforms to Multivariate Data Analysis. A Review
}

\author{
Catarina Silva ${ }^{1}\left(\mathbb{D}\right.$, Rosa Perestrelo $^{1}{ }^{1}$, Pedro Silva ${ }^{1}$, Helena Tomás ${ }^{1,2}$ and José S. Câmara ${ }^{1,2, *}$ (i) \\ 1 CQM - Centro de Química da Madeira, Universidade da Madeira, Campus Universitário da Penteada, \\ 9020-105 Funchal, Portugal; cgsluis@staff.uma.pt (C.S.); rmp@staff.uma.pt (R.P.); \\ pedro_dasilva@hotmail.com (P.S.); lenat@staff.uma.pt (H.T.) \\ 2 Faculdade de Ciências Exactas e Engenharia, Universidade da Madeira, Campus Universitário da Penteada, \\ 9020-105 Funchal, Portugal \\ * Correspondence: jsc@staff.uma.pt; Tel.: +351-291-705-5112
}

Received: 7 February 2019; Accepted: 17 May 2019; Published: 22 May 2019

\begin{abstract}
Cancer is a major health issue worldwide for many years and has been increasing significantly. Among the different types of cancer, breast cancer (BC) remains the leading cause of cancer-related deaths in women being a disease caused by a combination of genetic and environmental factors. Nowadays, the available diagnostic tools have aided in the early detection of $\mathrm{BC}$ leading to the improvement of survival rates. However, better detection tools for diagnosis and disease monitoring are still required. In this sense, metabolomic NMR, LC-MS and GC-MS-based approaches have gained attention in this field constituting powerful tools for the identification of potential biomarkers in a variety of clinical fields. In this review we will present the current analytical platforms and their applications to identify metabolites with potential for $\mathrm{BC}$ biomarkers based on the main advantages and advances in metabolomics research. Additionally, chemometric methods used in metabolomics will be highlighted.
\end{abstract}

Keywords: breast cancer; omics; analytical platforms; chemometric methods

\section{Introduction}

Cancer is a public health problem and causes a tremendous burden on patients, families and society creating a significant problem on global economy. Although has been extensively investigated, cancer still remains one of the leading causes of death in the world after coronary diseases [1]. Globally, breast cancer (BC) remains at the top of women's cancers worldwide followed by colorectal, lung, cervix, and stomach cancers according to GLOBOCAN series of the International Agency for Research on Cancer (IARC), contributing with more than $11.6 \%$ of all cancer types (Figure 1).
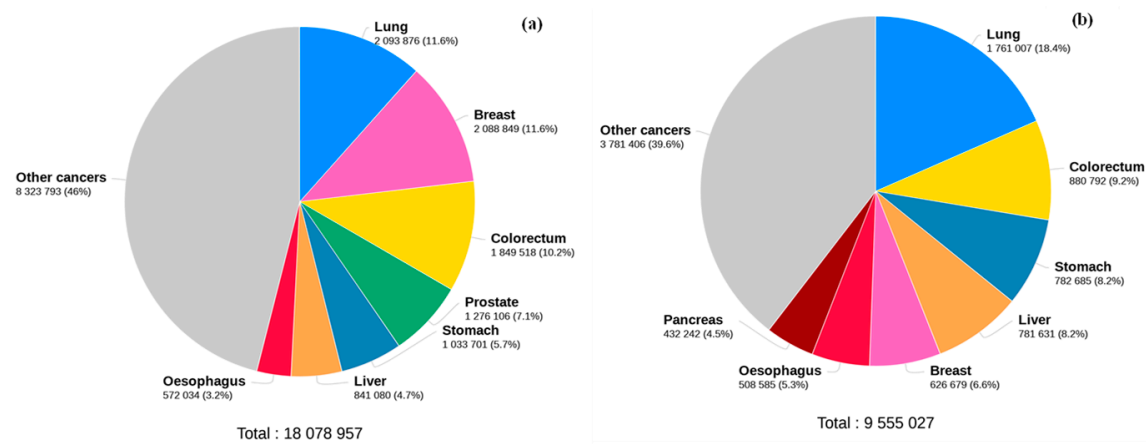

Figure 1. Estimated cancer incidence rates (a) and (b) estimated number of deaths worldwide for 2018. Adapted from GLOBOCAN [2]. 
In addition, around 2.1 million BC new cases were diagnosed in 2018 and occurred 630 thousand deaths (6.6\% of all cancers) (Figure $1 b)$.

The incidence rates are highest in North America, Australia and Europe and lowest in Asia. These differences might be related to societal changes, as result of industrialization, such as, unhealthy lifestyle, expressed by overweight and other symptoms, alcohol consumption, tobacco smoking, physical inactivity, early menarche, among others [2,3]. Although the incidence is high in some developed countries, mortality is higher in low and middle income countries [4]. The incidence of breast cancer increases with age and is usually diagnosed in the 50-60 age group. Moreover, the most aggressive type of the disease predominates in the younger age group (below 35 years) whereas in the older age group (above 75 years), the treatment cannot be so aggressive and has to be adjusted [5]. Concerning the incidence rates and mortality for breast cancer in Europe, it was observed that in 2012, the incidence of breast cancer was around 361,608 cases with 91,585 deaths. For 2020, around 400 thousand new cases will be diagnosed resulting in 100 thousand deaths according to International Agency for Research on Cancer (IARC). For Portugal and USA the expected number of breast cancer cases in 2020 will be nearly 6000 and 270 thousand resulting in around 1700 and 51,000 deaths, respectively as shown in Figure 2.

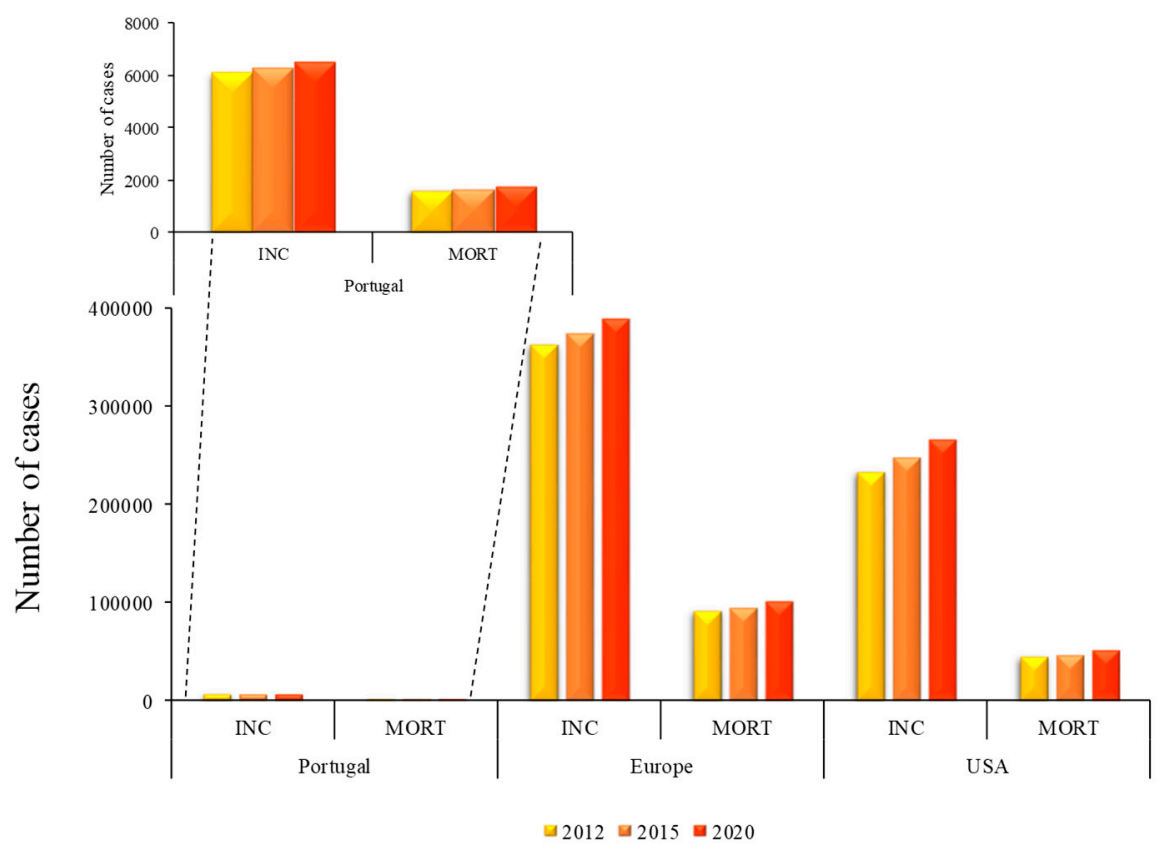

Figure 2. BC incidence and mortality rates in Portugal, Europe and USA from 2012, 2015 and expected rates for 2020. Data available at IARC. Legend: INC: incidence; MORT: mortality.

This trend might be as consequence by the availability of better screening procedures resulting in an early detection and also in the development of new treatments $[3,6,7]$, which lead to an improved survival. Several risk factors associated with $\mathrm{BC}$ have been already recognized, namely epidemiological factors (e.g., age, reproductive factors, socioeconomic status, ethnicity), often using standard analysis approaches (e.g., logistic regression) with adjustment for multiple comparisons. Other factors as lifestyle (e.g., alcohol, tobacco, obesity, physical activity), and exposure to radiation [8] are also associated. The risk of developing $\mathrm{BC}$ increases with age being rare in women younger than 25 years, but tending to be more aggressive in younger people. The most common $\mathrm{BC}$ that occurs is the invasive type independently of age [9]. The highest risk of family history is associated with increasing number of first-degree relatives diagnosed with BC (age under 50 years). The risk is further increased when the affected relative is diagnosed in both breasts [10]. Particularly, the mutations in genes BRCA1, BRCA2 and TP53 are strongly associated with the development of BC [9], even if these mutations are low, accounting for a small portion of the total BC incidence [2]. Consistent physical activity has many 
benefits and greater activity has been related to lower BC risk by decreasing the circulating estrogen levels in postmenopausal women [11,12]. Extensive literature has linked alcohol consumption to BC risk and reveal the role of ethanol in carcinogenesis altering estrogen levels through acetaldehyde. Briefly ethanol is converted to acetaldehyde (AA) through alcohol dehydrogenase (ADH), that then binds to DNA interfering with the DNA synthesis and repair [13]. Obesity is another BC risk factor to take into account as it is involved in insulin resistance and hyperinsulinemia [14]. Insulin has anabolic effects on cellular metabolism and an overexpression of insulin receptor has been demonstrated in human cancer cells [9,15]. The involvement of insulin-like growth factor (IGFs) in carcinogenesis is attributed to their role in linking high energy intake, increased cell proliferation, and suppression of apoptosis to cancer risks $[15,16]$. With regard to obesity and BC risk, some studies indicate that is strongly associated with increased invasive $\mathrm{BC}$ risk in postmenopausal women particularly for estrogen receptor-positive cancers $\left(\mathrm{ER}^{+}\right)$[17-19]. In clinical practice, there are nowadays several biomarkers routinely used for prognosis and identification of tumors, including the estrogen receptor (ER), progesterone receptor (PR) and the human epidermal growth factor receptor-2 (HER2) [20,21]. Another promising prognostic and predictive biomarker of BC is $\mathrm{Ki}-67$ (present in dividing cells) as indicator of cell proliferation and also as an endpoint for neoadjuvant systemic therapy [20]. However there are other proposed markers of proliferation measured by immunohistochemistry (IHC), such as, cyclin D, cyclin E, p27, p21, among others that are used to determine the predictive and prognostic levels [22].

In the last years, metabolomics emerged as a powerful approach in the advanced disease biomarker discovery which includes the comprehensive study of metabolites that are present in biological samples [23]. The study of metabolome to search biomarkers for any disease involves the identification of endogenous metabolites that have the potential to discriminate between samples obtained from healthy subjects and diseased patients. Plasma, serum, urine, tissue and cerebrospinal fluid (CSF), are the most commonly used biological samples in metabolomic studies. These biological samples contain hundreds of metabolites that vary in chemical and physical properties and concentration levels. Metabolomic studies includes two main approaches - targeted and untargeted. The targeted analysis is focused in specific groups of chemical characterized and annotated metabolites and their related pathways, whereas in the untargeted analysis the study includes a comprehensive measurement of all metabolites present in samples [24,25].

The type of approach chosen will determine the experimental design, sample preparation, and which analytical techniques can be used to obtain the results. Both targeted and untargeted follow the similar pipeline. Briefly, the study design includes the population that will be part in the study and also the determination of the conditions that are relevant for the hypothesis in investigation, namely the sample size, randomization (as a study design consideration), storage (as a sample handling issue), freeze/thaw cycles and timing during sample preparation are the most common factors that should be taken into account to guarantee reproducible and successful experiments minimizing variability. There are three main analytical platforms frequently used in metabolomic studies, which include mass spectrometry (MS) and nuclear magnetic resonance (NMR) spectroscopy [26]. Moreover, after data acquisition, the obtained dataset, normally is subjected to statistical analysis (univariate and multivariate methods) to find significant variations that allow the discrimination of patients with a specific disease (in this case, BC) from a control group [27]. The most common approaches for the identification of important metabolites comprise the application of unsupervised methods, such as, principal component analysis (PCA), hierarchical cluster analysis (HCA), as well as supervised methods, like partial least squares discriminant analysis (PLS-DA), random forest (RF) and support vector machines (SVM) $[26,28]$. A training set is used to construct the multivariate analysis models (e.g., PCA or PLS-DA), followed by an external validation set to predict the new cohort of samples using the model constructed with the training model. Finally, the putative biomarkers can be placed in metabolic networks to allow the biological interpretation or which pathways are up- or down-regulated. 


\section{OMICS Science}

The OMICs is a neologism broadly adopted in biomedical research, that comprises the dataset of genomics (DNA), transcriptomics (RNA), proteomics (proteins) and metabolomics (metabolites) based on the central dogma of molecular biology [29]. The purpose of OMICs science in cancer research is to discover cancer-specific biomarkers (diagnostic, prognostic and/or putative). The Food and Drug Administration (FDA) defined biomarkers as a "characteristic that is objectively measured and evaluated as an indicator of normal biological processes, pathogenic processes, or biological responses to a therapeutic intervention" [30]. Biomarkers are powerful tools, when used for the early cancer detection and selection of therapeutic strategy, thus improving the outcome of cancer treatment and reduce cancer-related mortalities.

One of the newest promising OMICs sciences is metabolomics being a suitable tool that provides state of the art of analytical instrumentation tandem with pattern recognition procedures and chemometric tools to discover new disease- biomarkers providing novel insights into disease etiology, and more robust assessment of etiological pathways [30,31]. Metabolomics studies the complex interaction in biological systems providing a comprehensive and detailed information of the phenotype and molecular physiology as result of environmental factors, genetic as well as exogenous and endogenous factors (e.g., age, gender, race, diet, drugs, exercise, gut microbiota) [31]. In addition, metabolomics can be used in early detection and diagnosis of cancer, in the assessment of therapies and medical interventions, since cancer is a disease that promotes changes in cellular metabolism [32-35]. This OMICs tool has been extensively applied in clinical health practice due to its ability to quickly analyze biological samples (e.g., blood, tissue, saliva and urine) with relatively simple sample preparation (10-30 min), cost-effective and high-throughput [30,36,37]. Nevertheless, metabolomics present several drawbacks resulting from biological and experimental features, such as sampling variability, inter- and intra-individual differences and a lack of validated protocols for biological samples handling which have a significant impact on the OMICs data approach [38,39].

The current review is focused in the metabolic profile of several biological samples, including lipidomics (lipids), labeled substrates (e.g., ${ }^{13}$ C labeled glucose), volatomic (volatile organic metabolites), and metabolites resulting from Krebs cycle [30,39] with the purpose of an early diagnosis, metabolic reprogramming, cancer typing, staging and therapeutic intervention response [29,37]. Regarding the Krebs/TCA cycle, there is evidence that the role of TCA for energy production and macromolecule synthesis by cancer cells, especially those with dysregulated oncogene and tumor suppressor expression [40-42]. Over the last years, there has been a rapidly growing number of metabolomic studies intended to discover new biomarkers or make disease diagnosis using different biological matrices, such as cell lines [43-46], blood [47], exhaled breath [48], plasma [33,49,50], saliva [51-54], tissues [55-57], serum [58] and urine [59]. In Table 1 are resumed the most common analytical approaches used in metabolomic studies grouped by type of biological sample and objective of the study. Interestingly, the main studies involve a diagnostic purpose using BC cell lines with the aim of search biomarkers, inspect the metabolome (endo- and exo-). Moreover, lipids as building blocks of cell membranes have their levels changed during the malignant transformation. Lipid metabolism plays a vital role in oxidative stress and is correlated with other parameters linked to BC risk (e.g., hormonal balance, body mass index, breast density, drug metabolism and growth of insulin levels) $[43,60]$. In addition, a summary of the total identified metabolites by analytical platform as well as the number of samples used for each biological specimen type is shown as Supplementary Materials (Figure S1). 
Table 1. Summary of metabolomics studies performed in breast cancer biomarker discovery in different biological matrices.

\begin{tabular}{|c|c|c|c|c|c|}
\hline Biological Sample & Sample Groups & Aim & Analytical Approaches & Main Conclusions & References \\
\hline Human cell lines & - & - & - & - & - \\
\hline Diagnostic biomarkers & $\begin{array}{l}\text { BC (ZR-75-1, T-74D, MCF7, } \\
\text { MDA-MB-231, MDA-MB-453, } \\
\text { MDA-MB-468, SK-BR-3, BT-474, } \\
\text { BT-549), Control (MCF10A) }\end{array}$ & $\begin{array}{l}\text { To compare the differences in the } \\
\text { lipidomic compositions of human } \\
\text { cell lines derived from normal and } \\
\text { BC tissues, and tumor vs. normal } \\
\text { tissues obtained after the surgery of } \\
\text { BC patients. }\end{array}$ & LC-MS/MS, GC-MS & $\begin{array}{l}\text { *123 lipids were identified, and a differentiation } \\
\text { was observed for MDA cells }\end{array}$ & {$[29,43]$} \\
\hline Diagnostic biomarkers & $\begin{array}{l}\text { BC (MDA-MB-231, -453, BT-474), } \\
\text { Control (MCF-10A) }\end{array}$ & $\begin{array}{l}\text { To determine endo- and } \\
\text { exo-metabolite analysis of the BC } \\
\text { cell lines }\end{array}$ & UPLC-MS/MS, LC-MS/MS & $\begin{array}{c}\text { * } \text { Statistical analysis allowed a discrimination of } \\
\text { the breast epithelial cells from the BC cell lines } \\
\text { * MDA-MB-231 showed an increase in } \\
\text { nicotinamide levels, namely in } \\
\text { 1-ribosyl-nicotinamide and NADp }\end{array}$ & [46] \\
\hline Diagnostic biomarkers & $\begin{array}{c}\text { BC (T-47D, MDA-MB-231, MCF-7) } \\
\text { Control (HMEC) }\end{array}$ & $\begin{array}{l}\text { To establish the } \mathrm{BC} \text { cell lines } \\
\text { volatile metabolomic signature }\end{array}$ & GC-MS & $\begin{array}{l}\text { * } 60 \text { VOMs were identified and six of them were } \\
\text { detected only in the headspace of cancer cell } \\
\text { lines }\end{array}$ & [44] \\
\hline Diagnostic biomarkers & BC (MDA-MB-468, SKBR3, MCF-7) & $\begin{array}{l}\text { To quantify specific metabolites in } \\
\text { BC cell extracts }\end{array}$ & NMR & $\begin{array}{l}{ }^{*} \text { Significantly differences were observed } \\
\text { between cell lines, namely in the concentrations } \\
\text { of } 15 \text { metabolites } \\
\text { * The current method represented a useful tool } \\
\text { for the establishment of potential biomarkers }\end{array}$ & [61] \\
\hline Diagnostic biomarkers & BC (Cal 51, SKBR3, MCF-7) & $\begin{array}{c}\text { To measure the absolute metabolite } \\
\text { concentrations in complex mixtures } \\
\text { with a high precision in a } \\
\text { reasonable time }\end{array}$ & NMR & $\begin{array}{l}\text { * The proposed approach represented a } \\
\text { powerful tool to quantify } 14 \text { metabolites } \\
\text { (alanine, lactate, leucine, threonine, taurine, } \\
\text { glutathione, glutamate, glutamine, choline, } \\
\text { valine, isoleucine, myo-inositol, proline, and } \\
\text { glucose) in cell extracts within } 20 \text { min }\end{array}$ & [45] \\
\hline Diagnostic biomarkers & $\begin{array}{l}\text { BC cell lines (MCF-7, HCC70, } \\
\text { MDA-MB-231, MDA-MB-436, } \\
\text { MDA-MB-468), BC patients }(n=35)\end{array}$ & $\begin{array}{l}\text { To investigate the metabolic profiles } \\
\text { of human BC cell lines carrying } \\
\text { BRCA1 pathogenic mutations }\end{array}$ & LC-MS/MS & $\begin{array}{l}\text { * It was possible to collect differential metabolic } \\
\text { signature for BC cells based on the BRCA1 } \\
\text { functionality }\end{array}$ & [50] \\
\hline Therapy response & BC cell line (MCF-7) & $\begin{array}{c}\text { To develop a robust and highly } \\
\text { sensitive platform to identify } \\
\text { endogenous estrones in clinical } \\
\text { specimens }\end{array}$ & MALDI-MS, LC-MS/MS & $\begin{array}{l}\text { *The results suggested that MALDI-MS-based } \\
\text { quantitative approach can be a broad method for } \\
\text { the ketone-containing metabolites target } \\
\text { analysis thus replicating the clinical stage. }\end{array}$ & [62] \\
\hline Therapy response & $\begin{array}{l}\text { BC tissue }(n=40), \text { Blood }(n=27) \\
\text { BC cell lines }(n=3)\end{array}$ & $\begin{array}{l}\text { To detect alterations in metabolites } \\
\text { and their linkage to metabolic } \\
\text { processes in several pathological } \\
\text { conditions including BC }\end{array}$ & NMR & $\begin{array}{l}\text { * Functional of IP3Rs in causing metabolic } \\
\text { disruption was observed in MCF-7 and MDA } \\
\text { MB-231 cells } \\
\text { * The results offered new insights regarding the } \\
\text { relationship of BC metabolites with IP3R. }\end{array}$ & [63] \\
\hline
\end{tabular}


Table 1. Cont.

\begin{tabular}{|c|c|c|c|c|c|}
\hline Biological Sample & Sample Groups & Aim & Analytical Approaches & Main Conclusions & References \\
\hline Metabolic reprogramming & MDA-MB-231, BC xenografts & $\begin{array}{l}\text { To study toxic effects of bisphenol } \\
\text { and the underlying mechanisms on } \\
\text { tumor metastasis-related tissues }\end{array}$ & LC-MS/MS, MALDI-MS & $\begin{array}{l}\text { * Metabolites-based studies might be suitable for } \\
\text { BC diagnosis } \\
{ }^{*} \text { The data provided good indication for BPA } \\
\text { screening secure option }\end{array}$ & [64] \\
\hline $\begin{array}{l}\text { Human Blood, plasma, } \\
\text { serum }\end{array}$ & - & - & - & - & - \\
\hline Diagnostic biomarkers & $\begin{array}{c}\text { BC patients }(n=258) \text {, Benign } \\
\text { mammary gland }(n=159) \text {, Control } \\
(n=78)\end{array}$ & $\begin{array}{l}\text { To screen metabolite markers with } \\
\text { BC diagnosis potentials }\end{array}$ & MS & $\begin{array}{l}\text { * The method developed allowed the } \\
\text { discrimination of BC from non-BC using six } \\
\text { blood metabolites }\end{array}$ & [47] \\
\hline Diagnostic biomarkers & $\begin{array}{l}\text { Metastatic BC patients }(n=95), \\
\text { Early-stage BC patients }(n=80)\end{array}$ & $\begin{array}{c}\text { To explore whether serum } \\
\text { metabolomic spectra could } \\
\text { distinguish between early and } \\
\text { metastatic BC patients and predict } \\
\text { disease relapse }\end{array}$ & NMR & $\begin{array}{l}\text { * Disease relapse was linked with lower and } \\
\text { higher levels of histidine and glucose, } \\
\text { respectively }\end{array}$ & {$[58]$} \\
\hline Diagnostic biomarkers & $\begin{array}{c}\mathrm{BC} \text { patients }(\mathrm{n}=132), \text { Control }(n= \\
76)\end{array}$ & $\begin{array}{l}\text { To develop a new computational } \\
\text { method using personalized } \\
\text { pathway dysregulation scores for } \\
\text { disease diagnosis }\end{array}$ & LC-TOF-MS, GC-TOF-MS & $\begin{array}{l}\text { * The method allowed to determine important } \\
\text { metabolic pathways signature for BC diagnosis, } \\
\text { representing a suitable tool for diagnostic and } \\
\text { therapeutic interventions. }\end{array}$ & [65] \\
\hline Diagnostic biomarkers & $\begin{array}{c}\text { BC patients }(n=45), \text { Control }(n= \\
45)\end{array}$ & $\begin{array}{l}\text { To detect differences between } \mathrm{BC} \\
\text { and healthy individuals }\end{array}$ & UHPLC-MS, GC-MS & $\begin{array}{l}\text { * } 661 \text { metabolites were detected, but only } 338 \\
\text { metabolites were found in all samples, and } 490 \\
\text { in more than } 80 \% \text { of samples. }\end{array}$ & [66] \\
\hline Diagnostic biomarkers & $\begin{array}{c}\text { BC patients }(n=29), \text { Control }(n= \\
29)\end{array}$ & $\begin{array}{c}\text { To establish a plasma metabolic } \\
\text { fingerprint of Colombian Hispanic } \\
\text { women with BC }\end{array}$ & LC-MS, GC-MS, NMR & $\begin{array}{l}\text { * The current report showed the effectiveness of } \\
\text { multiplatform strategies in metabolic/lipid } \\
\text { fingerprinting works }\end{array}$ & [49] \\
\hline Diagnostic biomarkers & $\begin{array}{c}\text { BC patients }(n=91), \text { Control }(n= \\
20)\end{array}$ & $\begin{array}{l}\text { To explore whether serum } \\
\text { metabolomic profile can } \\
\text { discriminate the presence of human } \\
\text { BC irrespective of the cancer } \\
\text { subtype }\end{array}$ & LC-MS/MS & $\begin{array}{l}\text { * From the } 1269 \text { metabolites identified in plasma } \\
\text { from controls and patients; only } 35 \text { metabolites } \\
\text { were related to BC. }\end{array}$ & [33] \\
\hline Diagnostic biomarkers & BC patients $(n=27)$, control $(n=30)$ & $\begin{array}{l}\text { To apply } 1 \mathrm{H} \text { NMR and DART-MS } \\
\text { for the metabolomics analysis of } \\
\text { serum samples from BC patients } \\
\text { and healthy controls. }\end{array}$ & NMR, DART-MS & $\begin{array}{l}\text { * The approach allowed the disease classification } \\
\text { and the biochemical validation useful to identify } \\
\text { the mechanisms associated to } \mathrm{BC} \text { development. }\end{array}$ & [67] \\
\hline Diagnostic biomarkers & $\begin{array}{l}\text { Metastatic } \mathrm{BC} \text { patients }(n=39+51 \\
\text { for validation), Early-stage BC } \\
\text { patients }(n=85+112 \text { for } \\
\text { validation) }\end{array}$ & $\begin{array}{l}\text { To distinguish between early and } \\
\text { metastatic BC }\end{array}$ & NMR & $\begin{array}{l}{ }^{*} \text { Metabolic phenotyping by NMR showed a } \\
\text { robust potential for the diagnosis, prognosis, } \\
\text { and management of BC cancer patients }\end{array}$ & [68] \\
\hline
\end{tabular}


Table 1. Cont

\begin{tabular}{|c|c|c|c|c|c|}
\hline Biological Sample & Sample Groups & Aim & Analytical Approaches & Main Conclusions & References \\
\hline Diagnostic biomarkers & $\begin{array}{l}\text { BC patients }(n=40) \text { BE patients }(n \\
=40) \text { and healthy controls }(n=34) \text {. } \\
\text { BE patients with fibroma }(n=25) \\
\text { and chronic fibroadenosis of breast } \\
\qquad(n=15)\end{array}$ & $\begin{array}{l}\text { To investigate the free fatty acid } \\
\text { (FFA) metabolic profiles to identify } \\
\text { biomarkers that can be used to } \\
\text { distinguish patients with BC (BC) } \\
\text { from benign (BE) patients or } \\
\text { healthy controls. }\end{array}$ & GC-MS & $\begin{array}{l}\text { The FFA biomarkers proved to be helpful for the } \\
\text { prevention and characterization of } B C \text { patients. }\end{array}$ & [69] \\
\hline Therapy response & BC patients $(n=19)$ & $\begin{array}{c}\text { To compare metabolite } \\
\text { concentrations and Pearson's } \\
\text { correlation coefficients to examine } \\
\text { concomitant changes in metabolite } \\
\text { concentrations and } \\
\text { psychoneurologic symptoms before } \\
\text { and after chemotherapy. }\end{array}$ & UPLC-MS/MS & $\begin{array}{l}\text { * The post-chemotherapy global metabolites } \\
\text { were characterized by higher and lower } \\
\text { amounts of acetyl-L-alanine and indoxyl sulfate } \\
\text { and 5-oxo-L-proline, respectively. } \\
\text { * Metabolomics was useful for further } \\
\text { understanding of biological mechanisms } \\
\text { associated with psychoneurologic symptoms. }\end{array}$ & [70] \\
\hline Therapy response & BC patients ( $n=28)$ & $\begin{array}{l}\text { To identify potential biomarker } \\
\text { candidates that can predict } \\
\text { response to neoadjuvant } \\
\text { chemotherapy for BC }\end{array}$ & LC-MS, NMR & $\begin{array}{l}\text { * The concentrations of threonine, isoleucine, } \\
\text { glutamine, linolenic acid had significantly } \\
\text { different responses to chemotherapy } \\
\text { * The purposed approach clearly discriminates } \\
\text { patients regarding the response to drugs } \\
\text { providing a valuable tool for a non-invasive } \\
\text { prognosis of the treatment strategy. }\end{array}$ & [71] \\
\hline Endogenous factors &  & $\begin{array}{l}\text { To investigate whether plasma } \\
\text { untargeted metabolomic profiles } \\
\text { could contribute to predict the risk } \\
\text { of developing BC }\end{array}$ & NMR & $\begin{array}{l}\text { * The study contributed to the development of } \\
\text { screening approaches for the identification of BC } \\
\text { at-risk women. }\end{array}$ & [31] \\
\hline Endogenous factors & BC patients $(n=621)$, Control $(n=$ & $\begin{array}{l}\text { To evaluate associations of } \\
\text { diet-related metabolites with the } \\
\text { risk of BC in the prostate, lung, } \\
\text { colorectal and ovarian cancer } \\
\text { screening trial }\end{array}$ & GC-MS, LC-MS/MS & $\begin{array}{l}\text { * The data obtained showed how nutritional } \\
\text { metabolomics might identify diet-related } \\
\text { exposures associated to cancer risk. }\end{array}$ & [72] \\
\hline Human urine & - & - & - & - & - \\
\hline Diagnostic biomarkers & $\begin{array}{c}\text { BC patients }(n=30), \text { CC }(n=30), \\
\text { Control }(n=30)\end{array}$ & $\begin{array}{l}\text { To discriminate different types of } \\
\text { cancer based on urinary volatomic } \\
\text { biosignature }\end{array}$ & GC-MS & $\begin{array}{l}\text { * The butanoate metabolism was highly } \\
\text { activated in studied cancers, as well as tyrosine } \\
\text { metabolism, but in a reduced proportion } \\
\text { * Different clusters allowed to establish sets of } \\
\text { VOMs fingerprints resulted in the } \\
\text { discrimination of the studied cancers }\end{array}$ & [59] \\
\hline Therapy response & $\begin{array}{c}\text { BC patients }\left(\begin{array}{c}n=31), \text { Control }(n= \\
29)\end{array}\right.\end{array}$ & $\begin{array}{l}\text { To identify metabolites which can } \\
\text { be helpful in the understanding of } \\
\text { metabolic alterations driven by BC } \\
\text { as well as their potential usage as } \\
\text { biomarkers }\end{array}$ & LC-MS, GC-MS & $\begin{array}{c}\text { * The analytical multiplatform approach enabled } \\
\text { a wide coverage of urine metabolites revealing } \\
\text { significant alterations in BC samples }\end{array}$ & [73] \\
\hline
\end{tabular}


Table 1. Cont.

\begin{tabular}{|c|c|c|c|c|c|}
\hline Biological Sample & Sample Groups & Aim & Analytical Approaches & Main Conclusions & References \\
\hline Human Saliva & - & - & - & - & - \\
\hline Diagnostic biomarkers & $\begin{array}{l}\text { BC patients (primary, } n=8 \text {; relapse, } \\
n=22) \text {, Control }(n=14)\end{array}$ & $\begin{array}{c}\text { To determine polyamines including } \\
\text { N-acetylated forms in human saliva } \\
\text { and the diagnostic approach to BC } \\
\text { Patients }\end{array}$ & UPLC-MS/MS & $\begin{array}{l}\text { * The increase on polyamines level in BC patients } \\
\text { Ac-SPM, DAc-SPD, and DAc-SPM levels were } \\
\text { significantly higher only in the relapsed patients }\end{array}$ & [52] \\
\hline Diagnostic biomarkers & $\begin{array}{c}\text { BC patients }(n=30), \text { Control }(n= \\
25)\end{array}$ & $\begin{array}{l}\text { To screen the potential salivary } \\
\text { biomarkers for BC diagnosis, } \\
\text { staging, and biomarker discovery. }\end{array}$ & UPLC-MS & $\begin{array}{l}\text { * Saliva metabonomics approach may provide } \\
\text { new insights into the discovery of BC diagnostic } \\
\text { biomarkers. }\end{array}$ & [53] \\
\hline Diagnostic biomarkers & BC patients $(n=111)$, Control $(n=$ & $\begin{array}{l}\text { To determine of polyamines } \\
\text { including their acetylated } \\
\text { structures for the diagnosis of BC } \\
\text { patients. }\end{array}$ & UPLC-MS/MS & $\begin{array}{l}{ }^{*} \text { The ratio of N8-Ac-SPD/ (N1-Ac-SPD + } \\
\text { N8-Ac-SPD) can be used as a health status index } \\
\text { after the surgical treatment. }\end{array}$ & [54] \\
\hline Diagnostic biomarkers & $\begin{array}{c}\text { BC patients }(n=66) \text {, Control }(n= \\
40)\end{array}$ & $\begin{array}{l}\text { To explore the potential of the } \\
\text { volatile composition of saliva } \\
\text { samples as biosignatures for BC } \\
\text { non-invasive diagnosis }\end{array}$ & GC-MS & $\begin{array}{l}{ }^{*} \text { This study defined an experimental layout } \\
\text { appropriate for the characterization of volatile } \\
\text { fingerprints from saliva as potential } \\
\text { biosignatures for BC non-invasive diagnosis. }\end{array}$ & [51] \\
\hline Human Exhaled breath & - & - & - & - & - \\
\hline Diagnostic tool & $\begin{array}{c}\text { BC patients }(n=14), \text { Control }(n= \\
11)\end{array}$ & $\begin{array}{l}\text { To detect and identify human } \\
\text { exhaled BC-related volatile profile }\end{array}$ & MS & $\begin{array}{l}\text { * Eight metabolites enabled a clear } \\
\text { discrimination of exhaled breath of BC patients } \\
\text { from controls. } \\
\text { * The analytical technique provided a } \\
\text { non-invasive strategy to detect VOMs for the BC } \\
\text { diagnosis. }\end{array}$ & [48] \\
\hline Human Tissues & - & - & - & - & - \\
\hline Diagnostic biomarkers & BC patients $(n=10)$ & $\begin{array}{l}\text { To establish a detailed lipidomic } \\
\text { characterization with the goal to } \\
\text { find the statistically differences } \\
\text { between } B C \text { and normal tissues. }\end{array}$ & HPLC-MS & $\begin{array}{c}\text { * Total concentrations for phosphatidylinositols, } \\
\text { phosphatidylcholines, } \\
\text { phosphatidylethanolamines and } \\
\text { lysophosphatidylcholines were increased } \\
\text { leading to a clear differentiation by PCA and } \\
\text { OPLS-DA. }\end{array}$ & [55] \\
\hline Diagnostic biomarkers & $\begin{array}{l}\text { Paired tumor and non-tumor liver } \\
(n=60), \text { breast }(n=130) \text { and } \\
\text { pancreatic }(n=76)\end{array}$ & $\begin{array}{l}\text { To assess the metabolomic profiling } \\
\text { as a novel tool for multiclass cancer } \\
\text { characterization }\end{array}$ & GC-MS, LC-MS & $\begin{array}{l}\text { * The findings provided a framework to validate } \\
\text { cancer-type specific metabolite levels in tumor } \\
\text { tissues. }\end{array}$ & [56] \\
\hline Diagnostic biomarkers & BC patients $(n=37)$, Control $(n=$ & $\begin{array}{l}\text { To identify potential biomarkers } \\
\text { that differs TNBC from } \mathrm{ER}^{+} \mathrm{BC}\end{array}$ & GC-MS, LC-MS/MS & $\begin{array}{l}\text { *133 metabolites presented significant } \\
\text { differences between } \mathrm{ER}^{+} \text {and TNBC tumors } \\
\text { * The metabolic pathway of tumors can provide } \\
\text { new treatment targets. }\end{array}$ & [57] \\
\hline
\end{tabular}


Table 1. Cont.

\begin{tabular}{|c|c|c|c|c|c|}
\hline Biological Sample & Sample Groups & Aim & Analytical Approaches & Main Conclusions & References \\
\hline Diagnostic biomarkers & $\begin{array}{c}\text { BC patients }(n=47), \text { Control }(n= \\
35)\end{array}$ & $\begin{array}{l}\text { To identify how TNBC differs from } \\
\text { LABC subtypes within the } \\
\text { African-American and Caucasian BC } \\
\text { patients }\end{array}$ & HR-MAS-NMR & $\begin{array}{l}\text { * Increased pyrimidine synthesis was related to } \\
\text { TNBC in Caucasian women } \\
\text { * Novel treatment targets for TNBC could be } \\
\text { explored through the metabolic changes }\end{array}$ & [74] \\
\hline Diagnostic biomarkers & BC patients $(n=228)$ & $\begin{array}{l}\text { To distinguish between tumor and } \\
\text { non-involved adjacent tissue }\end{array}$ & HR-MAS-NMR & $\begin{array}{l}{ }^{*} \text { Metabolic profiling of tumor tissues by NMR } \\
\text { can be a suitable method for the analysis of the } \\
\text { resection margins during BC surgery }\end{array}$ & [75] \\
\hline Diagnostic biomarkers & BC patients $(n=25)$, Control $(n=5)$ & $\begin{array}{l}\text { To establish metabolic profiles of } \mathrm{ER}^{+} \\
\text {vs. } \mathrm{ER}^{-} \text {and of } \mathrm{ER}^{-} \text {subtypes linked } \\
\text { to genetics }\end{array}$ & GC-MS, LC-MS & $\begin{array}{c}{ }^{*} \text { Changes in the metabolic profile of ER- vs. ER } \\
+ \text { breast tumors were observed } \\
{ }^{*} \text { The data represents a potential tool for the } \\
\text { hypothesis testing of tumor metabolism }\end{array}$ & [76] \\
\hline Diagnostic biomarkers & $\begin{array}{c}\text { BC patients }\left(\begin{array}{c}n=270), \text { Control }(n= \\
97)\end{array}\right.\end{array}$ & $\begin{array}{l}\text { To quantify the dysregulation of the } \\
\text { glutamate-glutamine equilibrium in } \\
\qquad \text { BC }\end{array}$ & GC-TOFMS & $\begin{array}{l}{ }^{*} \text { A positive correlation between glutamate and } \\
\text { glutamine in normal breast tissues was } \\
\text { observed, whereas a negative correlation was } \\
\text { obtained for normal tissues }\end{array}$ & [77] \\
\hline Diagnostic biomarkers & $\begin{array}{l}95 \text { OC ( } 84 \text { peritoneal, } 11 \text { pleural), } 10 \\
\text { BC ( } 7 \text { pleural, } 2 \text { peritoneal, } 1 \\
\text { pericardial), and } 10 \text { malignant } \\
\text { mesotheliomas ( } 6 \text { peritoneal, } 4 \\
\text { pleural) }\end{array}$ & $\begin{array}{l}\text { To identify the metabolic differences } \\
\text { between ovarian serous carcinoma } \\
\text { effusions obtained pre- and } \\
\text { post-chemotherapy and compare } \\
\text { ovarian carcinoma (OC) effusions } \\
\text { with breast carcinoma and malignant } \\
\text { mesothelioma specimens. }\end{array}$ & 1H-NMR & $\begin{array}{l}\text { * Differences in metabolic profiles of different } \\
\text { malignant effusions were detected } \\
\text { * Metabolic characterization by NMR can be a } \\
\text { technique to additional knowledge the } \\
\text { mechanisms of effusion development }\end{array}$ & [78] \\
\hline Therapy response & BC patients $(n=122)$ & $\begin{array}{l}\text { To explore the effect of neoadjuvant } \\
\text { therapy on metabolic profiles of BC } \\
\text { tissues }\end{array}$ & HR-MAS-NMR & $\begin{array}{l}\text { * Non-metastatic breast tumor tissue reflected } \\
\text { different alterations in all patient groups after } \\
\text { treatment. } \\
\text { * Metabolic profiles discriminated pNRs from } \\
\text { pMRD patients thus complementing other } \\
\text { molecular assays allowing the knowledge of the } \\
\text { underlying mechanisms affecting the response. }\end{array}$ & [79] \\
\hline Therapy response & BC patients $(n=18)$ & $\begin{array}{l}\text { To study metabolite levels in human } \\
\text { BC tissue, assessing, for instance, } \\
\text { correlations with prognostic factors, } \\
\text { survival outcome or therapeutic } \\
\text { response }\end{array}$ & HR-MAS-NMR & $\begin{array}{l}\text { * Significant changes between the tumors were } \\
\text { identified, indicating that the intertumoral } \\
\text { changes for numerous metabolites were greater } \\
\text { than the intratumoral changes for these three } \\
\text { tumors. }\end{array}$ & [80] \\
\hline Therapy response & BC patients $(n=37)$ & $\begin{array}{l}\text { To determine whether metabolic } \\
\text { profiling of core needle biopsy (CNB) } \\
\text { samples using HR-MAS-NMR could } \\
\text { be used for predicting pathologic } \\
\text { response to neoadjuvant } \\
\text { chemotherapy (NAC) in patients } \\
\text { with locally advanced BC }\end{array}$ & HR-MAS-NMR & $\begin{array}{l}\text { * The purposed method can be applied to } \\
\text { predict the pathologic response before } \\
\text { neoadjuvant chemotherapy }\end{array}$ & [81] \\
\hline
\end{tabular}


Table 1. Cont.

\begin{tabular}{|c|c|c|c|c|c|}
\hline Biological Sample & Sample Groups & Aim & Analytical Approaches & Main Conclusions & References \\
\hline Therapy response & $\mathrm{BC}$ patients $(n=271)$ & $\begin{array}{l}\text { To establish metabolic signatures } \\
\text { for } \mathrm{ER}^{+} \mathrm{vs} \text {. } \mathrm{ER}^{-} \mathrm{BC}\end{array}$ & GC-TOFMS & $\begin{array}{l}\text { Some metabolites levels were increased in } \mathrm{ER}^{-} \\
\text {subtype, such as, beta-alanine, glutamate and } \\
\text { xanthine } \\
\text { The down-regulation of the ABAT protein in } \\
\mathrm{ER}^{-} \mathrm{BC} \text { was confirmed by immunohistological } \\
\text { analysis. }\end{array}$ & [82] \\
\hline Mouse $B C$ tissue & - & - & - & - & - \\
\hline Metabolic reprogramming & $\begin{array}{l}\text { MMTVPyMT, MMTV-PyMT-DB, } \\
\text { MMTV-Wnt1, MMTV-Her2/neu, } \\
\text { and C3(1)-SV40 T-antigen (C3-TAg) }\end{array}$ & $\begin{array}{l}\text { To identify global metabolic } \\
\text { profiles of breast tumors isolated } \\
\text { from multiple transgenic mouse } \\
\text { models and to identify unique } \\
\text { metabolic signatures driven by } \\
\text { these oncogenes }\end{array}$ & $\begin{array}{l}\text { GC-MS, LC-MS/MS, } \\
\text { CE-MS }\end{array}$ & $\begin{array}{l}{ }^{*} \mathrm{C} 3-\mathrm{TAg} \text { was the only cohort with a tumor } \\
\text { metabolic signature composed of ten metabolites } \\
\text { with significance prognostic value in BC patients }\end{array}$ & [83] \\
\hline
\end{tabular}

ANOVA - Analysis of variance; AUC - Area under the curve; BC - BC; BFS- Bootstrap feature selection; CE-MS - Capillary electrophorese-mass spectrometer; DART-MS - Direct analysis in real time mass spectrometry; GC-MS - gas chromatography - mass spectrometry; GC-TOF-MS - Gas chromatography time-of-flight mass spectrometry; GGM - Gaussian graphical modelling; HCA - Hierarchical cluster analysis; HR-MAS-NMR - High resolution magic angle spinning nuclear magnetic resonance spectroscopy; LC-MS/MS - Liquid chromatography tandem with mass spectrometer; LC-TOF-MS - Liquid chromatography time-of-flight mass spectrometry; LDA - Linear discriminant analysis; MALDI-MS - Matrix-assisted laser desorption/ionization mass spectrometry; MCCV - Monte Carlo cross validation; MS - Mass spectrometry; MWT - Mann Whitney U test; NMR - Nuclear resonance magnetic; NRI - Net reclassification improvement; OPLS-DA - Orthogonal projections to latent structures discriminant analysis; OSC-PLS - Orthogonal signal correction partial least squares; PC - Pearson correlation; PCA - Principal component analysis; PEA - Pathway enrichment analysis; PLS-DA - Partial least squares discriminant analysis; RF - Random Forest classifier; ROC - Receiver operating characteristic; SCC - Spearman correlation coefficient; SVM - Support vector machine; TNBC - Triple negative BC; UPLC-MS/MS - Ultra performance liquid chromatography tandem mass spectrometer; VIP - variable importance in projection; VOMs - volatile organic metabolites. 
In literature, the reports performed involving human cell lines focus mainly in diagnostic purpose. As for example in the volatile composition (VOMs) as described by Silva et al. [44] where the volatomic signature of BC cell lines was established, and based on the results, 2-pentanone, 2-heptanone, 3-methyl-3-buten-1-ol, ethyl acetate, ethyl propanoate and 2-methyl butanoate were detected only in cultured BC cell lines. These VOMs are formed endogenously or obtained from exogenous sources (e.g., environmental, lifestyle, biological agents) [51], and can be recognised as a useful tool to BC non-invasive diagnosis [44,51]. Other study by Willmann et al. [46] observed the changes of the exoand endometabolite profiles in BC cell lines by LC-MS/MS and observed a clear discrimination of the breast epithelial from the BC cell lines through statistical tools. Moreover, a decrease on ratio of glutathione (GSH) and glutathione disulfide (GSSG) was observed in BC cell lines as a result of oxidative stress. The lipidomic profile of several BC cell lines was compared with normal cells obtained from non-cancerous tissues by LC-MS/MS and GC-MS that changes observed in breast tumor tissues were caused mainly by difference in lipidomic profiles of tumor cells and these alterations can be correlated with the lipidomic composition of the nine breast cancer cell lines. Furthermore, Martineau et al. [61], determined the absolute concentration of several metabolites (e.g., alanine, lactate, threonine, taurine, glutathione, glutamate, glutamine, choline, valine, isoleucine, myo inositol, serine, proline, aspartate and histidine), revealing the usefulness for the establishment of potential biomarkers. Also, BC cell lines with BRCA1 pathogenic mutations were investigated by LC-MS/MS in order to obtain their metabolic signature as possible diagnostic approach.

Regarding plasma, serum or blood, many studies have been conducted as observed in Table 1, with multiple aims as Cala et al. [49] that developed a pilot control case-study, where a metabolomic and lipidomic approach was performed in order to establish a plasma metabolic fingerprint of Colombian Hispanic women with BC. According to these authors, the plasma metabolites could contribute to an enhanced knowledge of the underlying metabolic shifts driven by BC in women of Colombian Hispanic origin. Moreover, despite racial differences, the mapped metabolic signatures in BC were comparable but not identical to those described for non-Hispanic women. Wang et al. [47] used a dried blood spot approach for rapid BC detection. In the first study, the target analytes were 23 amino acids and 26 acylcarnitines, and based on the results piperamide, asparagine, proline, tetradecenoylcarnitine/palmitoylcarnitine, phenylalanine/tyrosine, and glycine/alanine could be used as potential biomarkers to diagnose BC. Lyon et al. [70] established a serum metabolome analysis from the tryptophan pathway of 19 women with early-stage BC. The targeted analysis indicated higher kynurenine levels and kynurenine/tryptophan ratios post-chemotherapy. Also, the symptoms of pain and fatigue had association with several targeted metabolites. An improved metabolic profile of human serum samples was obtained using complementary thecniques, namely MS and NMR and this approach may be useful to achieve more accurate disease detection and gain more insights regarding disease mechanisms and biology [67].

Another study conducted by Lécuyer et al. [31] combined metabolomic and epidemiological approaches by NMR to investigate whether plasma untargeted metabolomic profiles could contribute to the identification of BC at-risk women, whereas Playdon et al. [72] focused on the evaluation of the associations of diet-related metabolites with the risk of breast cancer. It was possible to verify that the prediagnostic serum concentrations of metabolites related to alcohol, vitamin E, and animal fats were associated with $\mathrm{ER}^{+}$breast cancer risk.

Urine became a very interesting biological sample to investigate as diagnostic tool or as result of a treatment, as it is easy to collect, and also as ending point of all reactions that occur in the body. Furthermore, Porto-Figueira [59] established the urinary volatomic biosignature from breast (BC), and colon (CC) cancer patients as well as healthy individuals. This last work observed that several pathways are over activated in cancer patients, being phenylalanine pathway in BC and limonene and pinene degradation pathway in CC the most relevant. Yu et al. [84] explored the relationship between urinary metabolites and clinical chemotherapy response in BC. As results, chemotherapy-sensitive patients exhibited $30 \%$ of change in metabolite levels when compared to 
healthy individuals, while chemotherapy-insensitive patients showed only $9 \%$ of change in metabolite levels when compared to healthy people that presented recurrence.

Another explored biological fluid is saliva as described by Zhong et al. [53] that screened the putative salivary biomarkers for $\mathrm{BC}$ diagnosis, staging, and biomarker discovery. As a result, 18 biomarkers were identified, but only three up-regulated metabolites, displayed the area under the curve (AUC) values higher than 0.920, indicating the high accuracy to predict BC. Also, Cavaco et al. [51] screened salivary volatiles for a putative BC discrimination, and from metabolites identified, only 3-methyl-pentanoic acid, 4-methyl-pentanoic acid, phenol, p-tert-butyl-phenol, acetic, propanoic, benzoic acids, 1,2-decanediol, 2-decanone, and decanal were statistically relevant for the discrimination of BC patients in the populations analyzed. Another type of molecules, the polyamines were associated with tumor growth due to their biosynthesis and accumulation [54]. In this context, Tsutsui et al. [52] and Takayama et al. [54] determined polyamines including $\mathrm{N}$-acetylated forms in saliva to diagnose BC. According to Tsutsui et al. [52], the level of polyamines increased in BC patients, and the levels of $N^{1}$-acetyl-spermine, $N^{1} N^{8}$-diacetyl-spermidine and $N, N$-diacetyl-spermine were significantly higher only in the relapsed patients. Takayama et al. [54] demonstrated that eight polyamines are strongly correlated with the BC patients. Furthermore, the ratio of $N^{8}$-acetyl-spermidine/ $\left(\mathrm{N}^{1}\right.$-acetylspermidine $+N^{8}$-acetyl-spermidine) may be adopted as an index of the health status after the surgical treatment.

In-vitro analysis of BC tissues can be a valuable tool to inspect the metabolic differences between tissue classes, either using the hydrophilic or the lipophilic part. As a result, one might use the metabolomic profile as a novel tool for cancer characterization. Breast tissue is also an interesting biological sample used for diagnostic purposes and /or response to a treatment as demonstrated by Euceda et al. [79] that explored the effect of the antiangiogenic drug bevacizumab on metabolic profile from BC tissue. On the other hand, Budczies et al. [77] studied the glutamate enrichment as a new diagnostic opportunity in $\mathrm{BC}$, and a positive correlation between glutamate and glutamine in normal breast tissues switched to negative correlation between glutamate and glutamine in $\mathrm{BC}$ tissues. Euceda et al. [79] observed a metabolic alteration indicating a decline in glucose consumption as an effect of chemotherapy. In addition, a lower glucose and higher lactate level was observed in patients ( $\geq 90 \%$ of tumor reduction) when compared to those with no response $(\leq 10 \%$ of tumor reduction). In turn, Choi et al. [81] determined the metabolic profiling of core needle biopsy samples in order to predict pathologic response to neoadjuvant chemotherapy in patients with locally advanced BC. These authors observed that there was a trend of lower levels of phosphocholine/creatine ratio and choline-containing metabolite concentrations in the pathologic complete response group when compared to the non-pathologic complete response group. Most of the BC patients undergo a cycle or more of chemo being the general treatment that uses cancer-killing drugs before (neoadjuvant or preoperative therapy) and after (adjuvant therapy) surgery [31,36], Then, the therapeutic chemo effect may shift significantly between patients, as a result of BC phenotypes [37] of and intra- and inter- individual differences. For this reason, it is necessary to punctually and accurately evaluate the therapeutic effects of chemotherapy, which could help to adjust the chemotherapy regimen $[71,84]$. whereas the advances in treatment increased significantly the survival rates for women with $\mathrm{BC}$, as women often report psychoneurologic symptoms (e.g., pain, fatigue, depression) during and after chemotherapy cycles.

Regarding exhaled breath a less explored biological sample in terms of $\mathrm{BC}$ diagnostic purpose. In a study performed by Martinez-Lozano Sinues et al. [48] who developed a pilot study to identify cancer-related volatile profile in exhaled breath of BC patients. Concerning exhaled breath and the possible mechanisms involved in the production of endogenous VOMs, in Figure 3 is represented a schematic illustration about the possible pathways. 


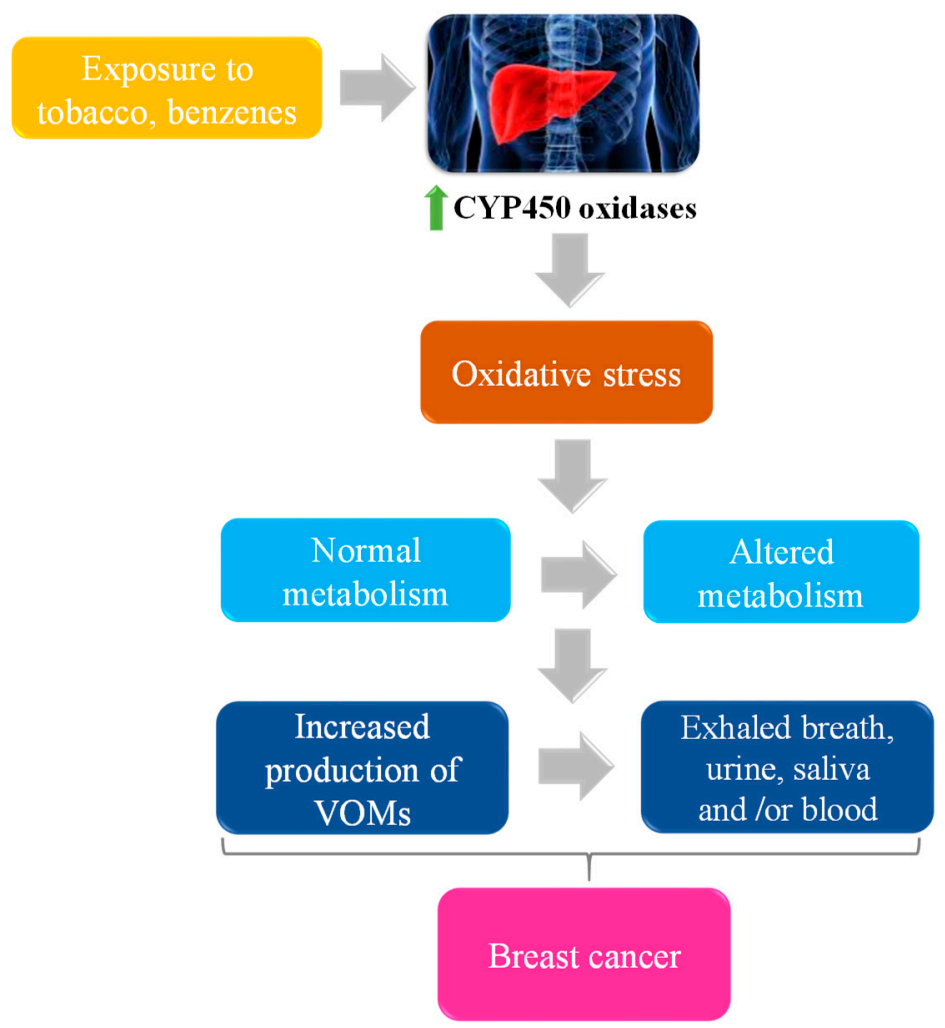

Figure 3. Schematic illustration of possible origin of some VOMs.

The principle behind this is based on the fact that the cancer growth is promoted by the progressive accumulation of genetic and epigenetic changes leading to cellular oxidative stress, which in turn increases the liver's production of cytochrome P-450 (CYP450) oxidase enzymes to take into account with stress. Both processes affect the abundance of VOMs in breath once oxidative stress causes lipid peroxidation of polyunsaturated fatty acids (PUFA) in membranes, producing alkanes and methylalkanes which are catabolized by CYP450 [85].

\section{Analytical Approaches}

Metabolomics encompasses targeted and non-targeted analysis of endogenous and exogenous metabolites ( $<1500 \mathrm{Da})$, such as lipids, amino acids, hormonal steroids, peptides, nucleic acids, organic acids, vitamins, thiols and carbohydrates, which represent a promising tool for biomarker discovery $[86,87]$. The complexity of the metabolome, the metabolites properties and their concentration levels in biological samples complicates the separation and detection on a single analytical platform. For this fact, the integration of high resolution analytical frameworks, mass spectrometry (MS) and nuclear magnetic resonance (NMR), appear as an outcome in metabolomics studies, providing sensitive, reliable detection and quantification of thousands of metabolites in a biological sample and related metabolic pathways within a few minutes $[27,86,87]$ as shown in Figure 4.

This review will provide an update of the most commonly used analytical methods in metabolomics, namely MS- and NMR- based metabolomics [27]. 


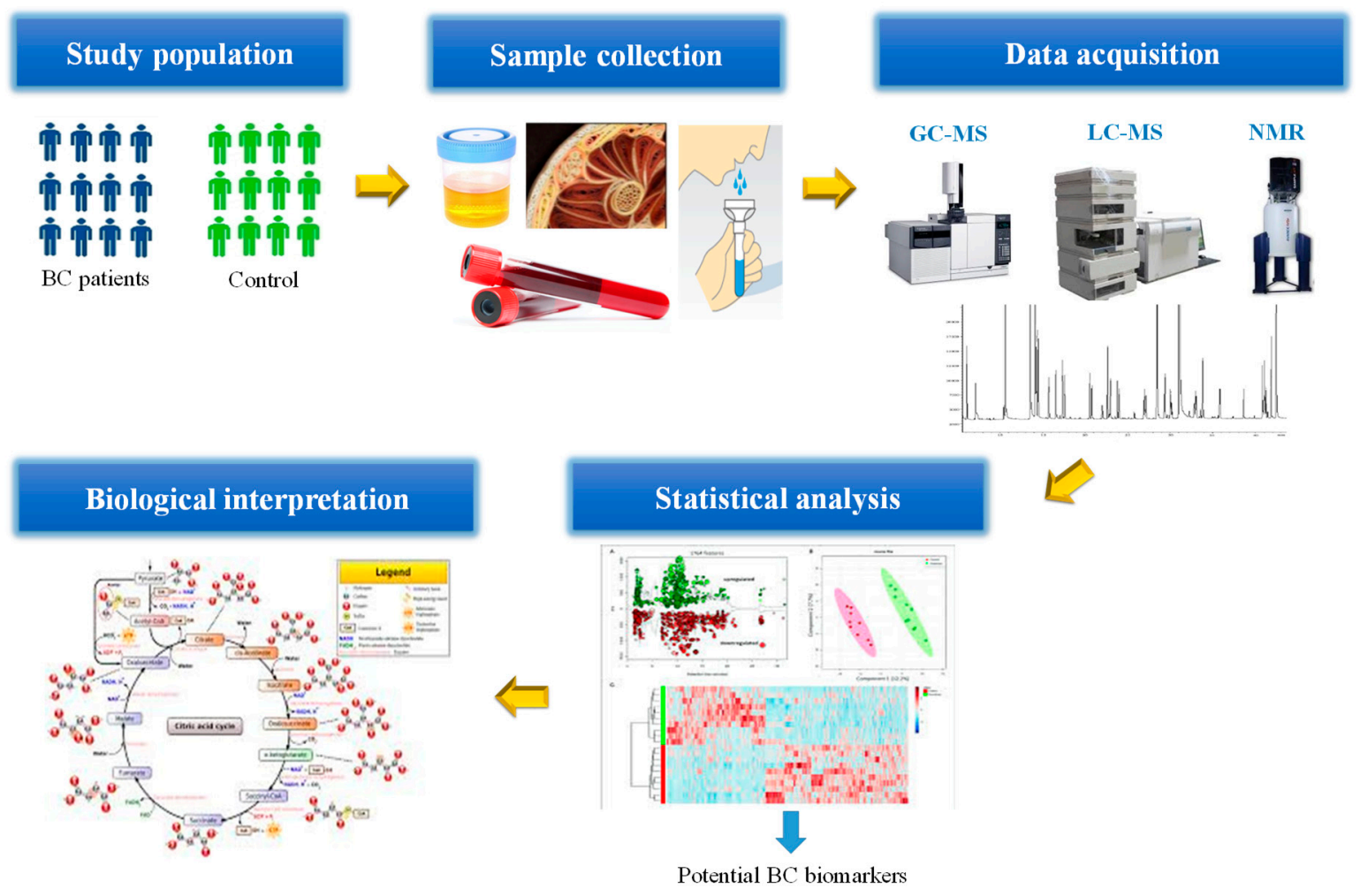

Figure 4. General flowchart in targeted/untargeted metabolomic approaches.

\subsection{MS-Based Metabolomics}

MS is an analytical tool extensively used in metabolomics applications, ranging from understanding the structural characterization of important metabolites to biomarker discovery [86]. Metabolic fingerprinting is general obtained by MS direct-injection, but this approach presents several drawbacks namely co-suppression and low ionization efficiency. Thus, generally MS based metabolomics includes a separation step, based on gas chromatography (GC-MS) $[43,44,51,59,65,66,77,82]$, liquid chromatography (LC-MS) [33,43,46,50,52-55,70] or capillary electrophoresis (CE-MS) [83,84], to solve the co-suppression and to decrease the complexity of the biological sample. The integration of MS with a chromatographic technique (GC, LC) and capillary electrophoresis showed high sensitivity, speed, selectivity and improves the accuracy of compound identification, detection and quantification. In addition, GC-, LC- and CE-MS are destructive methods, requires sample preparation and are expensive, being these facts the main drawbacks of these hyphenated frameworks $[86,88,89]$.

\subsubsection{Gas Chromatography-mass Spectrometry (GC-MS) - Based Metabolomics}

In the last decades, MS and chromatography have been broadly developed, and GC-MS becomes a core and reliable separation, detection and identification analytical framework on metabolomic analysis $[43,44,51,59,65,66,77,82]$. After sample collection and metabolite extraction, a small volume of sample is commonly injected in splitless mode, once the metabolites are in trace levels, to improve the sensitivity and the carrier gas propels the sample through the high-resolution capillary column (30 or $60 \mathrm{~m}$ columns with $5-50 \%$ phenyl stationary phases). The separation in GC occurs in an oven at high temperatures, and the metabolites need to be thermally stable and volatile (e.g., aldehydes, ketones, alkanes, organic acids) or non-volatile metabolites requiring derivatization (e.g., amino acids, sugars, phosphorylated metabolites, amines, lipids) $[86,88,89]$. The samples are ionized by electron-impact (EI) or chemical ionization (CI) for MS detection, being EI the most used since it provides molecular ion fragmentation to obtain a mass spectrum revealing of the metabolite's structure [88]. The MS employed influences the sensitivity of detection, being the quadrupole (q), time-of-flight (TOF) and 
ion trap the most usually applied in metabolomics. GC-qMS was used to screen salivary volatiles for putative $\mathrm{BC}$ as an exploratory study involving geographically distant populations [51], also to establish the metabolomic signature of human BC cell lines [44] and to discriminate different types of cancer based on urinary volatomic biosignature [59], among other examples reported in Table 1. In the first study, up to 120 volatiles from distinct chemical classes, with significant variations among the groups, were identified [51], whereas Silva et al. [44] and Porto-Figueira et al. [59] identified 60 and 130 volatiles in BC cell lines and urine, respectively. On the other hand, Budczies et al. [77,82] used GC-TOFMS framework to evaluate the glutamate enrichment as new diagnostic opportunity in $B C$ and to accomplish a comparative metabolomics of estrogen receptor positive $\left(\mathrm{ER}^{+}\right)$and estrogen receptor negative $\left(\mathrm{ER}^{-}\right)$in $\mathrm{BC}$. Budczies et al. [82] identified 19 metabolites $\mathrm{BC}$ tissues revealed significantly differences in central metabolism in $\mathrm{ER}^{-}$when compared to the $\mathrm{ER}^{+}$type. The affected metabolic pathways included the metabolism of glutamine with a decrease in concentration of glutamine and an increase glutamate and 2-hydroxyglutaric acid [82]. In turn, Dougan et al. [66] used GC-MS to evaluate the detectability, reliability, and distribution of metabolites measured in pre-diagnostic plasma samples in a pilot study of women listed in the Northern California site of the BC Family Registry. In this study. 661 metabolites were detected, 338 (51\%) of them were found in all samples, and $490(74 \%)$ in more than $80 \%$ of samples.

The main advantages of GC-MS-based metabolomics are sensitivity, specificity, high-throughput technology to handle a large volume of samples and reproducible. Nevertheless, this hyphenated technique has limited in mass range $(m / z 30-550)$, the molecular ion is often not detected owing to fragmentation, which makes more difficult the identification of unknown metabolites and the metabolites need be volatile and thermally stable $[89,90]$.

\subsubsection{Liquid Chromatography-Mass Spectrometry (LC-MS) - Based Metabolomics}

Currently, liquid chromatography (LC) in particular high-performance liquid chromatography-mass spectrometry (HPLC-MS, LC-MS) represents an easy-going tool on separation and characterization of a metabolites pool, namely salts, acids, bases, hydrophilic and hydrophobic metabolites. The versatility of LC-MS is due to the several separation procedures and wide-ranging mass analyzers [90]. Contrarily to GC-MS, HPLC-MS is not limited to volatile and thermo stable metabolites and it is a promising tool for global metabolomics and the establishment of disease biomarkers.

Basically, the metabolites are eluted through a column based on their selective partition between a stationary phase (column material) and a mobile liquid phase. The metabolites according to the type of stationary phase can be eluted based on their charge, size, hydrophobicity and molecular weight [91]. Nowadays, the evolution of the HPLC is focused in miniaturization, smaller columns and low solvent volumes to attain a faster separation of metabolites. Ultra-high performance chromatography (UHPLC) appears as solution, since compared to HPLC promotes the resolution within a low analysis time and requires low volumes of solvent [92,93]. UHPLC columns are packed with $2 \mu \mathrm{m}$ particles and the system operates at higher pressures (1000 bar) and tandem with MS, results in higher peak capacity, resolution, specificity and high-throughput abilities (reduced run time per sample) compared with HPLC [86,90,92-94].

Furthermore, Willmann et al. [46] analyzed the endo- and exometabolite of the BC cell lines MDA-MB-231, -453 and BT-474 as well as the breast epithelial cell line MCF-10A through two different analytical platforms: UHPLC-ESI-QTOF and HPLC-ESI-QqQ, which resulted in the identification of 92 annotated exometabolites and 58 endometabolites. In turn, Jové [33] used LC-ESI-QTOFMS/MS to establish the metabolomic profile of $\mathrm{BC}$, whereas HPCL-ESI-MS was used to determine the determine the lipidomic differences between human $\mathrm{BC}$ and the surrounding normal tissues [55]. UHPLC tandem with MS was applied to explore novel blood plasma biomarkers associated to the BRCA1-mutated phenotype of BC [50], to determine polyamines including $\mathrm{N}$-acetylated forms in saliva [52,54], and to screen the potential salivary biomarkers for BC diagnosis, staging, and biomarker discovery [53]. 


\subsection{NMR-Based Metabolomics}

NMR spectroscopy has been announced as a promising tool of metabolomics, providing a comprehensive view of metabolite fingerprinting, profiling and metabolic flux analysis under specific conditions, despite its inherent lower sensitivity compared to MS, limiting its skill with trace level metabolites. The main advantages of NMR are automation, requires low or no sample preparation, high reproducibility, non-destructive, non-selectivity in metabolite detection and the ability to simultaneously quantify multiple classes of metabolites [29,87].

The principle of NMR spectroscopy is based on the fact that the nucleic of many isotopes (e.g., ${ }^{1} \mathrm{H}$, ${ }^{13} \mathrm{C},{ }^{14} \mathrm{~N},{ }^{15} \mathrm{~N},{ }^{17} \mathrm{O}$ ), when placed in a magnetic field, absorb radiation at a specific frequency [90]. The result is a NMR spectrum which corresponds to a unique metabolite pattern and provides structural information that can simplify the identification of unknown metabolites [86,89]. A fast identification of metabolite results from a combination of chemical shifts, spin-spin coupling, and relaxation or diffusion information [86,89]. Jobard et al. [68] reported a ${ }^{1} \mathrm{H}$ NMR-based metabolic phenotyping study aiming the identification of metabolic serum changes associated with advanced metastatic BC (MBC) in comparison to the localized early disease (EBC). Histidine, acetoacetate, glycerol, pyruvate, glycoproteins ( $\mathrm{N}$-acetyl), mannose, glutamate and phenylalanine were the metabolites that allowed the discrimination between MBC and EBC groups. NMR was also used by Tenori et al. [58] to explore whether serum metabolomic spectra could distinguish between early and metastatic BC patients and predict disease relapse, whereas Singh et al. [63] used NMR to detect alterations in metabolites and their linkage to metabolic processes in a number of pathological conditions including BC. In the last study, the authors observed an increase in lipoprotein, lactate, lysine and alanine level and a decrease in the levels of pyruvate and glucose in serum of inositol 1, 4, 5-trisphosphate (IP3R) receptor group patients when compared to control. In addition, NMR offers the possibility to study tissue through high-resolution magic angle spinning (HR-MAS) to reduce line widths in NMR spectra of tissue samples [74,75,79-81]. Tayyari et al. [74] performed the metabolomic analysis of triple-negative and luminal A BC subtypes in African-American using HR-MAS-NMR. A total of 27 metabolites were assigned and the metabolic profiles of these subtypes were also distinct from those revealed in Caucasian women. In turn, the feasibility of HR-MAS-NMR of small tissue biopsies to distinguish between tumor and non-involved adjacent tissue was investigated by Bathen et al. [75]. The results showed that the levels of glucose were higher in samples with low tumor content, whereas samples with high tumor content presented higher levels of ascorbate, lactate, creatine, glycine, taurine and the choline-containing metabolites. Euceda et al. [79] evaluate the metabolomic changes during neoadjuvant chemotherapy combined with bevacizumab in BC using HR-MAS-NMR. According to these authors, despite metabolic profiles not being able to predict the pathological complete response $(\mathrm{pCR})$ prior to treatment, a significant metabolic difference in $\mathrm{pCR}^{+}$patients compared to $\mathrm{pCR}^{-}$was detected after neoadjuvant chemotherapy.

\subsection{Comprehensive Analytical Frameworks on Metabolomics Approach}

Comprehensive analytical frameworks have gained popularity on metabolomics field [86], being hundreds of metabolites detected simultaneously through analytical frameworks such as GC $\times$ GC-MS, HPLC-CE-MS, LC $\times$ LC-MS, LC-MS-NMR, MALDI-FT-ICR-MS, LC-FT-ICR-MS, among others. In the last decade, two dimension (2D) liquid-liquid chromatography (LC $\times$ LC) as well as gas-gas chromatography $(\mathrm{GC} \times \mathrm{GC})$ have been gained increasing attention since overcome overlapping of metabolites by diverting each peak from a GC or LC column to a second GC or LC column, improve sensitivity and complementary selectivity being a promising tool in metabolomics field [95]. Nevertheless, other comprehensive analytical framework has been purposed in metabolomic field, in this context LC-MS-NMR platform is used in the identification of unknown metabolites in biological samples at trace levels, providing sample efficiency higher than the conventional flow injection methods [86]. In this sense, Reichenbach and co-workers [96] developed a suitable approach based on GCXGC-HRMS to analyse a cohort of 18 samples from BC tumors. This approach avoided the 
intractable problem of comprehensive peak matching, through a few reliable peaks for alignment and peak-based retention-plane windows to define comprehensive features that can be consistently matched for cross-sample analysis. In addition, a clear discrimination was achieved between sample of different grades and establish potential BC biomarkers. On the other hand, Yu et al. [97] optimized GC $\times$ GC-MS for robust BC cells, tissue, serum and urine metabolite profiling. GC $\times$ GC-MS analysis revealed detection around 600 molecular features from which 165 were characterized representing different chemical groups, such as amino acids, fatty acids, lipids, carbohydrates, nucleosides and small polar components of glycolysis and the Krebs cycle using EI spectrum matching. NanoLC-FT-ICR MS was used to analyse protein digests of $\sim 3000$ laser capture microdissection (LCM)-derived tumor cells from breast carcinoma tissue, corresponding to $\sim 300 \mathrm{ng}$ of total protein [98].

\section{Data Analysis}

Data analysis is crucial in metabolomics, being indispensable in every step of research, namely in sampling and experiment designs, data pre-processing and metabolite identification, as well in variables selection, classification modeling and validation procedures. The great challenge of data analysis in metabolomics is the high dimensionality and complexity of datasets under analysis. Several chemometric tools and statistical softwares are used in order to attribute value for high-dimensional metabolomic information obtained previously by the analytical tools $[99,100]$. Normally, a complete data analysis procedure in metabolomics is based on the following steps: dataset pre-treatment (centering, scaling, normalization), pre-processing (exploratory projection, variables selection), processing (predictive models), validation (model verification) and post-processing (pathway analysis) [101]. However, data analysis is dependent on the objective of the study and may be a simple exploratory research or complex discovery of biomarkers and metabolic pathways, for this reason not all steps are always present or are not followed in the same order. The data analysis procedures of recent metabolomics studies in BC are described in Table 2. 
Table 2. Summary of the main chemometric methods applied to metabolomic studies.

\begin{tabular}{|c|c|c|c|c|c|c|}
\hline \multicolumn{7}{|c|}{ Data Analysis } \\
\hline Biological Sample & Data Pre-Treatment & Pre-Processing & Processing & Validation & Post-Processing & Reference \\
\hline Diagnostic tool & - & - & - & - & - & - \\
\hline \multirow{5}{*}{ Human BC cell lines } & $\begin{array}{l}\text { Scaling (Pareto scaled), } \\
\text { Transformation (log } \\
\text { transformed) }\end{array}$ & PCA, HCA & OPLS-DA & LOOCV, ROC & none & {$[43]$} \\
\hline & $\begin{array}{l}\text { Centering (mean centered), } \\
\text { Scaling (autoscaled) }\end{array}$ & $\begin{array}{l}\text { ANOVA, PCA, HCA, } \\
\text { Pearson correlation }\end{array}$ & PLS-DA & LOOCV & none & {$[46]$} \\
\hline & $\begin{array}{l}\text { Experimental correction } \\
\text { (sample weight corrected) }\end{array}$ & PCA & none & none & none & {$[61]$} \\
\hline & none & none & none & none & none & {$[45]$} \\
\hline & none & ANOVA, PCA & PLS, LDA & $\mathrm{K}-\mathrm{CV}$ & none & [44] \\
\hline \multirow[t]{2}{*}{ Human blood } & none & T-test & PLS-DA, LRA & $\begin{array}{l}\text { ROC, Permutation } \\
\text { test }\end{array}$ & none & [47] \\
\hline & $\begin{array}{l}\text { Scaling (total intensity value } \\
\text { scaled) }\end{array}$ & $\begin{array}{l}\text { Wilcoxon } \\
\text { test }\end{array}$ & $\mathrm{RF}$ & ROC, Bootstrapping & none & {$[58]$} \\
\hline $\begin{array}{l}\text { Human Exhaled } \\
\text { breath }\end{array}$ & $\begin{array}{l}\text { Transformation (quantile } \\
\text { transformed) }\end{array}$ & T-test & RF, SVM & $\begin{array}{l}\text { LOOCV, ROC, } \\
\text { Bootstrapping }\end{array}$ & none & {$[48]$} \\
\hline \multirow[t]{3}{*}{ Human plasma } & none & $\begin{array}{l}\text { Correlation feature } \\
\text { selection (CFS) }\end{array}$ & LRA, SVM, RF & $\mathrm{K}-\mathrm{CV}, \mathrm{ROC}$ & $\begin{array}{l}\text { Pathway-based } \\
\text { metabolite sets } \\
\text { analysis (pathifier) }\end{array}$ & [65] \\
\hline & $\begin{array}{c}\text { Scaling (median value scaled), } \\
\text { Transformation (log } \\
\text { transformed) }\end{array}$ & ANOVA, PCA & none & none & none & {$[66]$} \\
\hline & none & T-test, PCA, HCA & PLS-DA, RF & $\mathrm{K}-\mathrm{CV}, \mathrm{ROC}$ & $\begin{array}{c}\text { Pathway enrichment } \\
\text { analysis } \\
\text { (metaboanalyst) }\end{array}$ & [33] \\
\hline
\end{tabular}


Table 2. Cont

\begin{tabular}{|c|c|c|c|c|c|c|}
\hline \multicolumn{7}{|c|}{ Data Analysis } \\
\hline Biological Sample & Data Pre-Treatment & Pre-Processing & Processing & Validation & Post-Processing & Reference \\
\hline $\begin{array}{c}\text { Human BC cell lines, } \\
\text { plasma }\end{array}$ & none & KS-test, T-test, PCA & none & none & none & {$[50]$} \\
\hline \multirow{5}{*}{ Human saliva } & none & none & none & none & none & [52] \\
\hline & $\begin{array}{l}\text { Scaling (Pareto and total } \\
\text { intensity value scaled) }\end{array}$ & T-test, PCA & PLS-DA & $\begin{array}{l}\text { ROC, Permutation } \\
\text { test }\end{array}$ & none & [53] \\
\hline & none & none & LDA & $\mathrm{K}-\mathrm{CV}, \mathrm{ROC}$ & none & [54] \\
\hline & $\begin{array}{l}\text { Scaling (autoscaled and } \\
\text { median value scaled), } \\
\text { Transformation (cubic root } \\
\text { transformed) }\end{array}$ & MW-test, HCA & $\begin{array}{l}\text { PLS-DA, } \\
\text { OPLS-DA }\end{array}$ & $\begin{array}{c}\text { MCCV, Permutation } \\
\text { test }\end{array}$ & none & {$[51]$} \\
\hline & $\begin{array}{l}\text { Experimental correction } \\
\text { (internal standard corrected) }\end{array}$ & MW-test, PCA & $\begin{array}{l}\text { PLS-DA, SVM, } \\
\text { LRA }\end{array}$ & $\mathrm{K}-\mathrm{CV}, \mathrm{ROC}$ & none & [102] \\
\hline \multirow{8}{*}{ Human tissues } & Scaling (Pareto scaled) & PCA & OPLS & $\mathrm{K}-\mathrm{CV}$ & none & [55] \\
\hline & none & PCA, HCA & none & none & none & [56] \\
\hline & $\begin{array}{l}\text { Scaling (median scaled), } \\
\text { Transformation (log } \\
\text { transformed) }\end{array}$ & T-test & none & none & none & [57] \\
\hline & $\begin{array}{l}\text { Scaling (total intensity value } \\
\text { scaled) }\end{array}$ & T-test & PLS-DA & LOOCV, ROC & $\begin{array}{c}\text { Pathway enrichment } \\
\text { analysis } \\
\text { (metaboanalyst) }\end{array}$ & [74] \\
\hline & Scaling (median scaled) & PCA & PLS-DA & LOOCV & none & [75] \\
\hline & Scaling (median scaled) & T-test, PCA & PLS-DA & LOOCV & none & [78] \\
\hline & $\begin{array}{l}\text { Transformation (log } \\
\text { transformed) }\end{array}$ & $\begin{array}{l}\text { T-test, Pearson } \\
\text { correlation, HCA }\end{array}$ & none & none & none & [76] \\
\hline & none & $\begin{array}{l}\text { T-test, Pearson } \\
\text { correlation }\end{array}$ & PLS-DA & $\mathrm{K}-\mathrm{CV}, \mathrm{ROC}$ & none & [77] \\
\hline
\end{tabular}


Table 2. Cont

\begin{tabular}{|c|c|c|c|c|c|c|}
\hline \multicolumn{7}{|c|}{ Data Analysis } \\
\hline Biological Sample & Data Pre-Treatment & Pre-Processing & Processing & Validation & Post-Processing & Reference \\
\hline \multirow[t]{3}{*}{ Human serum } & $\begin{array}{l}\text { Centering (mean centered), } \\
\text { Scaling (total intensity value } \\
\text { scaled) }\end{array}$ & PCA & $\begin{array}{l}\text { PLS-DA, } \\
\text { OPLS-DA }\end{array}$ & $\mathrm{K}-\mathrm{CV}, \mathrm{ROC}$ & none & [67] \\
\hline & $\begin{array}{l}\text { Centering (mean centered), } \\
\text { Scaling (total intensity value } \\
\text { scaled) }\end{array}$ & T-test, PCA, ANOVA & OPLS & $\begin{array}{c}\text { K-CV, ROC, } \\
\text { Bootstrapping }\end{array}$ & none & {$[68]$} \\
\hline & $\begin{array}{c}\text { Transformation (log } \\
\text { transformed), Experimental } \\
\text { correction (internal standard } \\
\text { corrected) }\end{array}$ & ANOVA, PCA & PLS-DA, LRA & $\mathrm{K}-\mathrm{CV}, \mathrm{ROC}$ & none & [69] \\
\hline Human urine & $\begin{array}{c}\text { Scaling (autoscaled and } \\
\text { median value scaled), } \\
\text { Transformation (cubic root } \\
\text { transformed) }\end{array}$ & T-test, HCA & $\begin{array}{l}\text { PLS-DA, SVM, } \\
\text { RF }\end{array}$ & MCCV, ROC & $\begin{array}{c}\text { Pathway enrichment } \\
\text { analysis } \\
\text { (metaboanalyst) }\end{array}$ & [59] \\
\hline Drug therapy & - & - & - & - & - & - \\
\hline BC cell line & none & T-test & none & none & none & {$[62]$} \\
\hline Human blood & $\begin{array}{l}\text { Transformation (log } \\
\text { transformed) }\end{array}$ & $\begin{array}{l}\text { T-test, Pearson } \\
\text { correlation }\end{array}$ & none & none & none & {$[70]$} \\
\hline \multirow[t]{4}{*}{ BC tissues } & $\begin{array}{l}\text { Centering (mean centered), } \\
\text { Transformation (log } \\
\text { transformed - only in } \\
\text { univariate analysis) }\end{array}$ & $\begin{array}{l}\text { T-test, Pearson } \\
\text { correlation, PCA }\end{array}$ & PLS-DA & $\begin{array}{c}\mathrm{K}-\mathrm{CV} \text {, Permutation } \\
\text { test }\end{array}$ & none & [79] \\
\hline & $\begin{array}{c}\text { Scaling (mean scaled - only in } \\
\text { PCA) }\end{array}$ & $\begin{array}{l}\text { ANOVA, Spearman } \\
\text { correlation, PCA }\end{array}$ & $\mathrm{RF}$ & $\begin{array}{l}\text { K-CV, Bootstrapping, } \\
\text { Permutation test }\end{array}$ & none & [80] \\
\hline & $\begin{array}{l}\text { Scaling (total intensity value } \\
\text { scaled) }\end{array}$ & MW-test & OPLS-DA & LOOCV & none & [81] \\
\hline & none & Spearman correlation & none & none & none & [82] \\
\hline Serum & $\begin{array}{l}\text { Scaling (total intensity value } \\
\text { scaled) }\end{array}$ & T-test & PLS, PLS-DA & LOOCV, ROC & none & {$[71]$} \\
\hline
\end{tabular}


Table 2. Cont.

\begin{tabular}{|c|c|c|c|c|c|c|}
\hline \multicolumn{7}{|c|}{ Data Analysis } \\
\hline Biological Sample & Data Pre-Treatment & Pre-Processing & Processing & Validation & Post-Processing & Reference \\
\hline $\begin{array}{l}\text { Serum, tissues, cell } \\
\text { lines }\end{array}$ & none & T-test, ANOVA, PCA & PLS-DA & K-CV, ROC & $\begin{array}{c}\text { Pathway enrichment } \\
\text { analysis } \\
\text { (metaboanalyst) }\end{array}$ & [63] \\
\hline \multirow[t]{2}{*}{ Urine } & $\begin{array}{l}\text { Scaling (total intensity value } \\
\text { scaled) }\end{array}$ & $\begin{array}{c}\text { KS-test, L-test, } \\
\text { SW-test, T-test, PCA }\end{array}$ & OPLS-DA & K-CV, ROC & $\begin{array}{c}\text { Pathway enrichment } \\
\text { analysis } \\
\text { (metaboanalyst) }\end{array}$ & [73] \\
\hline & none & T-test, PCA & PLS-DA & $\mathrm{K}-\mathrm{CV}$ & none & {$[84]$} \\
\hline $\begin{array}{l}\text { Metabolic } \\
\text { reprogramming }\end{array}$ & - & - & - & - & - & - \\
\hline $\begin{array}{l}\text { Human BC cell lines, } \\
\text { BC xenografts }\end{array}$ & none & ANOVA, PCA & PLS-DA & $\mathrm{K}-\mathrm{CV}$ & none & {$[64]$} \\
\hline Mouse BC tissue & Scaling (median scaled) & ANOVA, PCA & none & none & none & [83] \\
\hline Endogenous factors & - & - & - & - & - & - \\
\hline Human plasma & none & $\begin{array}{l}\text { T-test, Spearman } \\
\text { correlation, PCA }\end{array}$ & LRA & ROC & none & {$[31]$} \\
\hline Human serum & $\begin{array}{l}\text { Transformation (log } \\
\text { transformed) }\end{array}$ & $\begin{array}{c}\text { Pearson correlation, } \\
\text { PCA }\end{array}$ & LRA & none & none & {$[72]$} \\
\hline
\end{tabular}




\subsection{Dataset Pre-Treatment}

Dataset pre-treatment is the initial step in data analysis, being extensively used in metabolomics to resolve the heteroscedasticity of high-dimensional datasets. Commonly, pre-treatment in BC metabolomics is done through normalization of dataset based on the centering, scaling, transformation and/or experimental corrections of variables values [103-105]. Centering is performed when the data analysis is focused on the differences between variables, where all measurements (e.g., concentrations, areas) are converted to values around zero based on variation measures. Mean $[46,67,68,79]$ is the measure normally used in centering. Scaling is used to adjust the variables measurements based on a scaling factor, converting the measurements of all variables into values relative to the scaling factor. The scaling factor selected can be a dispersive measure (e.g., standard deviation) or size measure (e.g., mean). The main scaling approaches based on dispersive measures are autoscaling (standard deviation) $[46,51,59]$ and pareto scaling (square root of the standard deviation) $[43,53,55]$. On the other hand, the most of size measure approaches uses scaling factors based on the mean [80], median [51,57,59,66,75,78,83] or total intensity value [53,58,67,68,71,73,74,81]. Transformations are mathematical approaches used to decrease the heteroscedasticity of dataset, which the variability between variables is dramatically reduce. $\log [43,57,66,69,70,72,76,79]$ is the main transformation in BC metabolomics. However, cubic root [51,59] and quantile [48] transformations are also used. Other normalization approaches based on experimental corrections are also used in metabolomics, such as internal standards [102,106] and sample weight [61]. Internal standards normalization assumes that the heteroscedasticity of all variables is systematic and can be corrected by variance of internal standards. Sample weight normalization is the direct correction of variables values by experimental sample measures (e.g., volume and weight).

\subsection{Pre-Processing}

Pre-processing methods are performed to obtain an exploratory projection of dataset or an overview of variables importance prior to prediction models processing. Primarily, normality tests are used to determine if the data distribution is normal (parametric) or not normal (non-parametric). The most commonly used are Kolmogorov-Smirnov test (KS-test) [50,73], Shapiro-Wilk test (SW-test) [73] and Lilliefors test (L-test) [73]. Two types of approaches are normally used in exploratory projections/variables importance ranking of BC metabolomics datasets: univariate and multivariate analysis. Univariate statistical methods are used to analyzed only one variable at a time, being useful to easily discover significant differences or measure correlations between samples groups. The differentiation is based on variance between groups by rejection of the null hypothesis or acceptation the alternate hypothesis $[101,107,108]$. The most common methods used when the data is parametric are T-tests [31,47,48,50,53,57,59,62,68,70,71,73,74,76-79,84] and ANOVA [33,44,46,63,64,66,68,69,72,83] T-tests, such as Student and Welch's tests, are recommended to analyze differences between two groups, and ANOVA-based methods, such as one-way ANOVA, two-way ANOVA, factorial ANOVA and MANOVA are used to evaluate more than two groups. Alternative univariate methods are implemented when the assumption of the normal distribution is non-parametric, such as Mann-Whitney test (MW-test) [51,81,102] and Wilcoxon test (W-test) [58]. In addition, univariate methods are also widely used to measure the correlations between continuous variables and response. The Pearson correlation $[46,70,72,76,77,79]$ is the preferred option for linear relationships in populations with normal distribution. On the other hand, the Spearman correlation $[31,80,82]$ is usually used in non-parametric datasets. More complex correlation methods are also used in data analysis, such as Correlation Feature Selection (CFS) [65], where the appropriate correlation measure and a heuristic search strategy are performed by experiments on artificial and natural datasets based on algorithms.

Similarly, the multivariate methods are also widely used for exploratory studies to obtain dataset patterns based on relationships between groups, being divided into two sub-groups, unsupervised and supervised methods. Unsupervised methods are the preferential option for exploratory studies, where the modeling process is based only on the explanatory variables, 
without external intervention of user (Yi et al., 2016). The most commons are principal component analysis (PCA) $[56,57,60,62,70,75,76,80,92,93]$ and hierarchical cluster analysis (HCA) $[33,43,51,56,59,76]$ PCA provides the projection of dataset into low dimensional based on orthogonal transformation, converting the variables variability from a set of observations into score vectors and loadings, called principal components $[100,109]$. HCA methods are used to form subsets of samples at ordered levels based on variables similarities/dissimilarities (such as distances or correlations) and can be performed in agglomerative mode (samples are aggregate into clusters) or divisive mode (complete dataset is divided into clusters). In both modes, the linkage criterion need to be selected, being that the most commonly used are single-linkage clustering (the minimum of distances) and complete linkage clustering (the maximum of distances) [110,111].

\subsection{Processing Methods}

After the explorative studies and variable selection, the next step is the processing of dataset in order to create a predictive response model to classification of new samples (ex. diagnostic tools), identification of valuable variables (ex. biomarkers) or exploring the mechanisms of metabolomic studies (ex. metabolic pathways). In this stage, the supervised methods are the preferential choice, where the response models are mainly based on two types, continuous (regression) and discrete (classification) [100,103]. The main methods for continuous response are based on multiple linear regression (MLR), sometimes called ordinary least squares (OLS). MLR is performed to predict the values of a dependent variable (response) based on a set of continuous explanatory variables, assuming a linear combination of the explanatory variables [109]. The most applied MLR-based method in metabolomics is partial least squares (PLS) [44,55,68,71]. Unlike PCA, which uses only the variables variation, PLS is a predictive and supervised method that use an informative response to maximize the covariance between the explanatory variables and the response, producing score vectors and loading vectors. The prediction model is based on interaction between the variables and response, ignoring the variables with irrelevant importance. The importance of each variable is defined according the PLS-based criteria, such as loading weights, variable importance on projection scores, regression coefficient, target projection and selectivity ratio [100,101,109]. However, when categorical variables are introduced, the discrete models should be used. Discrete models provide a predictive classification of response based on continuous and categorical variables, being classified into linear or non-linear. In linear methods, the classification is performed by highest probability based on linear relationships between explanatory variables, where exist a grouping variable (categorical). Linear discriminant analysis (LDA) [44,54] is the preferential method to classification models of discrete responses. LDA perform linear transformations of explanatory variables to create discriminant functions that will maximize the separation between multiple classes of samples (groups) based on the information of the categorical variables [109]. Among the various LDA-based methods, PLS-DA $[33,46,47,51,53,59,63,64,67,69,71,74,75,77,79,84,102]$ is most widely used in metabolomics studies. PLS-DA is a successful combination of PLS and LDA that provides a visual low-dimensional pattern of samples discrimination based on the analysis of relationships between continuous and categorical variables [101,109]. Recently, some extensions of PLS-DA were used in BC metabolomics, namely the OPLS-DA [43,51,67,73,81]. OPLS-DA separates out response orthogonal variations in rotations of the original component [109].

On the other hand, non-linear methods are used when metabolomics dataset follow a non-linear response. The most applied non-linear methods are support vector machines (SVM) $[48,59,65,102]$, random forests (RF) [33,48,58,59,65,80] and logistic regression analysis (LRA) [31,47,65,69,72,102]. SVM is a kernel-based model used for regression and classification of non-linear datasets, transforming the non-linear data into more general spaces (linear) by algorithm based on kernels functions. SVM perform the mapping of dataset into a high-dimensional space through kernels functions for the separation of two groups of samples into distinctive regions. The separation is based on support vectors, which are points (samples) on the boundary or on the incorrect side of the margin supporting the separation. SVM is a versatile method that transforms non-linear complex datasets into 
a high-dimensional space where classes are linearly separable [100,101,109]. RF is a non-linear method for regression and classification of high-dimensional datasets, where a large number of classification and regression trees are created by bootstrapping (replacement) based on random selection of a training samples from the original dataset. Afterwards, bootstrapping is performed systematically to build a large group of simple trees that are used to estimate classification accuracy of the model [100,101]. Another non-linear predictive method widely used is LRA, which is similar to linear regression, but with a binomial response variable. LRA is used to explain the relationship between one dependent binary variable and one or more nominal, ordinal, interval or ratio-level independent variables [112].

\subsection{Model Validation}

The validation of predictive models is a key step in data analysis of metabolomics studies. Validation process analyzes the performance/ability of model to predict correctly the hypothesized relationships between variables and responses [101]. Several validation methods have been used in BC metabolomics. The coefficient of determination $\left(\mathrm{R}^{2}\right)$ is the simplest method to evaluate the ability of predictive model, being used for continuous responses. The $\mathrm{R}^{2}$ is expressed as the ratio between 0 and 1, where a value of 1 indicates the perfect prediction. However, this validation is recommended for small datasets, due to fact that the $\mathrm{R}^{2}$ value tends to be increased when a predictor variable is added to the model [113]. However, in validation of predictive models used to high-dimensional and complex datasets, as the case of metabolomics studies, the cross validation (CV) methods are the preferential option. CV provides qualitative and quantitative analysis of the model ability to model's ability to predict new independent samples without collecting additional data. During the $\mathrm{CV}$, the available data are split into two sets, where one set is used to create a predictive model using the values of continuous and predictor variables (training set). The second set is used to test the performance of predictive model (validation set) [100]. The most applied CV procedure is k-fold (K-CV) [33,44,54,55,63-65,67-69,73,77,79,80,84,102]. K-CV processing is based on random partition of original dataset into equal sized subsamples (k). A single $\mathrm{k}$ subsample is used as the validation set for testing the model, and the remaining $\mathrm{k}-1$ subsamples are used as a training set. This process is then repeated $\mathrm{k}$ times (folds), with each of the $\mathrm{k}$ subsamples being used exactly one time as the validation set [106]. One special type of K-CV is the leave-one-out cross validation (LOOCV) (Bathen et al., 2013; Choi et al., 2013; Cífková et al., 2017; Martinez-Lozano Sinues et al., 2015; Tayyari et al., 2018; R. Vettukattil et al., 2013; Willmann et al., 2016), where the number of folds equals the number of $\mathrm{k}$ subsamples. LOOCV is considered an exhaustive CV, being recommend for small datasets [106,113]. Another type of CV is the Monte Carlo cross validation (MCCV) [51,59]. Although less used in metabolomics than LOOCV, MCCV is asymptotically consistent and showed better prediction ability. In MCCV proceeding, significant part of dataset is leaved out at a time during model validation, repeating systematically this procedure several times [114,115]. The $\mathrm{Q}^{2}$ value, which is the equivalent $\mathrm{R}^{2}$ value, is the preferential coefficient of determination for $\mathrm{CV}$ procedures.

A visual and easy model validation method is the receiver operating characteristic (ROC) curve $[31,33,43,47,48,53,54,58,59,63,65,67-69,71,73,74,77,102]$ which the prediction ability of a model is validated considering the specificity (ratio of the correctly predicted negatives) and sensitivity (ratio of correctly predicted positives). The ROC curve is given by plotting the sensitivity versus (1 - specificity) across a series of cutoff points. The area under curve (AUC) is a quantitative measure (between 0 and 1) of the ability of predictive model, where a AUC value close to 1 indicates a nearly perfect prediction response [100,113].

Random resampling-based methods are a robust alternative for model validation. The most used in BC metabolomics are bootstrapping $[48,58,68,80]$ and permutation tests $[47,51,53,79,80]$. Bootstrapping is a model validation based on replacement of samples, which can be considered non-parametric when the replacement is from the original dataset, or parametric when random noise is added from a recognized distribution to the dataset to estimate underlying sampling distribution or establish robust confidence intervals. Normally, in metabolomics studies the common approach is non-parametric 
bootstrapping $[113,116]$. Permutation tests provide the exact control of false positives from a predictive model (linear or non-linear), under minimal assumptions, based on differences between the randomly permuted response variables model and the original model. Permutation tests are based on a repeatedly permuting (repetitive reordering) of the $\mathrm{N}$ entries in the response variable. Permuted vectors containing integers between 1 and $\mathrm{N}$ are produced in a random number generator, creating new scrambled response variables only by switching their internal positions. The scrambled vectors are modelled one by one, where for every test, the $\mathrm{R}^{2}$ and $\mathrm{Q}^{2}$ values are calculated and saved. After, these values are compared with the values calculated from the original data. The results of permutation tests are displayed as a percentage overlap between the real and permuted $R^{2}$ and $Q^{2}$ values, where a $0 \%$ of overlap is the optimal result $[109,117]$.

\subsection{Post-Processing}

The post-processing step consists in the interpretation of metabolomic responses from original dataset. Normally, pathway analysis is the most used strategy to provide an overview of association/relationship between identified metabolites and metabolic pathways and other general biological networks. Pathifier [65] and metaboanalyst [33,59,63,73,74] are the most used software for this propose in metabolomics.

\section{Future Directions}

The advances in analytical techniques and chemometric methods in metabolomics have been growing rapidly becoming possible the identification of potential biomarkers. Furthermore, the integration of analytical platforms increases the comprehensive analysis of metabolites in biological samples. In this context, metabolites became valuable identifications, regardless their hierarchical source, enabling the phenotypic properties in a biological system. Additionally, the identification of key metabolic pathways from which significant metabolites are linked, it is possible to reveal potential targets for cancer therapy.

Also, standard procedures for sample collection, data analysis and shared in repositories have potential to be adopted by both researchers and medical communities.

Since the metabolome instantly responds to environmental stimuli including therapeutic or surgical intervention, could be also used to monitor the metabolic status of the individual and indicate any possible toxic effects. Moreover, metabolomics may help in the detection of potential cancer biomarkers, being useful for example in the development of different devices, including biosensors, that can significantly improve the cancer diagnosis. These devices include a biorecognition element within a biosensor system. The biorecognition molecules interact with the target, which is then converted into a measurable signal by a transducer. Basically, these molecules, usually enzymes or antibodies, can be immobilized on the transducer surface and interact with the target (biomarker) to produce a signal is interpreted, providing information about the disease and their possible recurrence after therapy.

Supplementary Materials: The following is available online at http://www.mdpi.com/2218-1989/9/5/102/s1, Figure S1: (a) Total identified metabolites by analytical technique and (b) number of samples used by each type of biological specimen.

Author Contributions: C.S. conception of the review, drafting of manuscript, performed the introduction, pathophysiology, risk factors, diagnostic and screening tools, future directions. R.P. performed the omics science and analytical platforms. P.S. performed the data analysis on chemometric tools. H.T. performed the supervision and revision of the manuscript. J.S.C. performed the supervision and revision of the manuscript. All authors read and approved the final version of manuscript.

Funding: This work was supported by FCT-Fundação para a Ciência e a Tecnologia (project PEst-OE/QUI/UI0674/2019, CQM, Portuguese Government funds, and INNOINDIGO/0001/2015), Madeira 14-20 Program (project PROEQUIPRAM - Reforço do Investimento em Equipamentos e Infraestruturas Científicas na RAM - M1420-01-0145-FEDER-000008) and by ARDITI-Agência Regional para o Desenvolvimento da Investigação Tecnologia e Inovação through the project M1420-01-0145-FEDER-000005 - Centro de Química da Madeira - CQM+ (Madeira 14-20). 
Acknowledgments: The authors also acknowledge the FCT for the Ph.D. grant SFRH/BD/97039/2013 and Post-Doctoral fellowship SFRH/BPD/97387/2013 given to Catarina L. Silva and Rosa Perestrelo. Pedro Silva acknowledge ARDITI through the Ph.D. grant under the M1420 Project - 09-5369-FSE-000001.

Conflicts of Interest: The authors declare no conflict of interest.

\section{References}

1. Donepudi, M.S.; Kondapalli, K.; Amos, S.J.; Venkanteshan, P. Breast cancer statistics and markers. J. Cancer Res. Ther. 2014, 10, 506-511. [PubMed]

2. Bray, F.; Ferlay, J.; Soerjomataram, I.; Siegel, R.L.; Torre, L.A.; Jemal, A. Global cancer statistics 2018: GLOBOCAN estimates of incidence and mortality worldwide for 36 cancers in 185 countries. CA Cancer J. Clin. 2018, 68, 394-424. [CrossRef] [PubMed]

3. Siegel, R.L.; Miller, K.D.; Jemal, A. Cancer statistics, 2018. CA Cancer J. Clin. 2018, 68, 7-30. [CrossRef]

4. Ferlay, J.; Soerjomataram, I.; Dikshit, R.; Eser, S.; Mathers, C.; Rebelo, M.; Parkin, D.M.; Forman, D.; Bray, F. Cancer incidence and mortality worldwide: Sources, methods and major patterns in GLOBOCAN 2012. Int. J. Cancer 2015, 136, E359-E386. [CrossRef]

5. Allison, K.H. Molecular Pathology of Breast Cancer. Am. J. Clin. Pathol. 2012, 138, 770-780. [CrossRef]

6. DeSantis, C.E.; Bray, F.; Ferlay, J.; Lortet-Tieulent, J.; Anderson, B.O.; Jemal, A. International Variation in Female Breast Cancer Incidence and Mortality Rates. Cancer Epidemiol. Biomarkers Prev. 2015, 24, 1495-1506. [CrossRef]

7. Ghoncheh, M.; Pournamdar, Z.; Salehiniya, H. Incidence and Mortality and Epidemiology of Breast Cancer in the World. Asian Pac. J. Cancer Prev. 2016, 17, 43-46. [CrossRef] [PubMed]

8. Verma, R.; Bowen, R.L.; Slater, S.E.; Mihaimeed, F.; Jones, J.L. Pathological and epidemiological factors associated with advanced stage at diagnosis of breast cancer. Br. Med. Bull. 2012, 103, 129-145. [CrossRef]

9. Shah, R.; Rosso, K.; Nathanson, S.D. Pathogenesis, prevention, diagnosis and treatment of breast cancer. World J. Clin. Oncol. 2014, 5, 283-298. [CrossRef]

10. Libson, S.; Lippman, M. A review of clinical aspects of breast cancer. Int. Rev. Psychiatry 2014, 26, 4-15. [CrossRef]

11. Maruti, S.S.; Willett, W.C.; Feskanich, D.; Rosner, B.; Colditz, G.A. A prospective study of age-specific physical activity and premenopausal breast cancer. J. Natl. Cancer Inst. 2008, 100, 728-737. [CrossRef] [PubMed]

12. Kyu, H.H.; Bachman, V.F.; Alexander, L.T.; Mumford, J.E.; Afshin, A.; Estep, K.; Veerman, J.L.; Delwiche, K.; Iannarone, M.L.; Moyer, M.L.; et al. Physical activity and risk of breast cancer, colon cancer, diabetes, ischemic heart disease, and ischemic stroke events: systematic review and dose-response meta-analysis for the Global Burden of Disease Study 2013. BMJ 2016, 354, i3857. [CrossRef] [PubMed]

13. McDonald, J.A.; Goyal, A.; Terry, M.B. Alcohol Intake and Breast Cancer Risk: Weighing the Overall Evidence. Curr. Breast Cancer Rep. 2013, 5. [CrossRef] [PubMed]

14. Maskarinec, G.; Jacobs, S.; Park, S.-Y.; Haiman, C.A.; Setiawan, V.W.; Wilkens, L.R.; Le Marchand, L. Type II Diabetes, Obesity, and Breast Cancer Risk: The Multiethnic Cohort. Cancer Epidemiol. Biomarkers Prev. 2017, 26, 854-861. [CrossRef]

15. Heidegger, I.; Ofer, P.; Doppler, W.; Rotter, V.; Klocker, H.; Massoner, P. Diverse Functions of IGF/Insulin Signaling in Malignant and Noncancerous Prostate Cells: Proliferation in Cancer Cells and Differentiation in Noncancerous Cells. Endocrinology 2012, 153, 4633-4643. [CrossRef] [PubMed]

16. Djiogue, S.; Nwabo Kamdje, A.H.; Vecchio, L.; Kipanyula, M.J.; Farahna, M.; Aldebasi, Y.; Seke Etet, P.F. Insulin resistance and cancer: the role of insulin and IGFs. Endocr. Relat. Cancer 2013, 20, R1-R17. [CrossRef]

17. Neuhouser, M.L.; Aragaki, A.K.; Prentice, R.L.; Manson, J.E.; Chlebowski, R.; Carty, C.L.; Ochs-Balcom, H.M.; Thomson, C.A.; Caan, B.J.; Tinker, L.F.; et al. Overweight, Obesity, and Postmenopausal Invasive Breast Cancer Risk. JAMA Oncol. 2015, 1, 611. [CrossRef] [PubMed]

18. Picon-Ruiz, M.; Morata-Tarifa, C.; Valle-Goffin, J.J.; Friedman, E.R.; Slingerland, J.M. Obesity and adverse breast cancer risk and outcome: Mechanistic insights and strategies for intervention. CA Cancer J. Clin. 2017, 67, 378-397. [CrossRef]

19. Moore, S.C.; Playdon, M.C.; Sampson, J.N.; Hoover, R.N.; Trabert, B.; Matthews, C.E.; Ziegler, R.G. A Metabolomics Analysis of Body Mass Index and Postmenopausal Breast Cancer Risk. JNCI J. Natl. Cancer Inst. 2018, 6, 588-597. [CrossRef] 
20. Kos, Z.; Dabbs, D.J. Biomarker assessment and molecular testing for prognostication in breast cancer. Histopathology 2016, 68, 70-85. [CrossRef]

21. Duffy, M.J.; Harbeck, N.; Nap, M.; Molina, R.; Nicolini, A.; Senkus, E.; Cardoso, F. Clinical use of biomarkers in breast cancer: Updated guidelines from the European Group on Tumor Markers (EGTM). Eur. J. Cancer 2017, 75, 284-298. [CrossRef] [PubMed]

22. Harris, L.N.; Ismaila, N.; McShane, L.M.; Andre, F.; Collyar, D.E.; Gonzalez-Angulo, A.M.; Hammond, E.H.; Kuderer, N.M.; Liu, M.C.; Mennel, R.G.; et al. Use of Biomarkers to Guide Decisions on Adjuvant Systemic Therapy for Women With Early-Stage Invasive Breast Cancer: American Society of Clinical Oncology Clinical Practice Guideline. J. Clin. Oncol. 2016, 34, 1134-1150. [CrossRef] [PubMed]

23. Jasbi, P.; Wang, D.; Cheng, S.L.; Fei, Q.; Cui, J.Y.; Liu, L.; Wei, Y.; Raftery, D.; Gu, H. Breast cancer detection using targeted plasma metabolomics. J. Chromatogr. B 2019, 1105, 26-37. [CrossRef] [PubMed]

24. Clish, C.B. Metabolomics: An emerging but powerful tool for precision medicine. Cold Spring Harb. Mol. Case Stud. 2015, 1, a000588. [CrossRef]

25. Roberts, L.D.; Souza, A.L.; Gerszten, R.E.; Clish, C.B. Targeted metabolomics. Curr. Protoc. Mol. Biol. 2012, 98, 30.2.1-30.2.24. [CrossRef]

26. Klupczyńska, A.; Dereziński, P.; Kokot, Z.J. Metabolomics in medical sciences-trends, challenges and perspectives. Acta Pol. Pharm. 2015, 72, 629-641. [PubMed]

27. Alonso, A.; Marsal, S.; Julià, A. Analytical methods in untargeted metabolomics: State of the art in 2015. Front. Bioeng. Biotechnol. 2015, 3, 23. [CrossRef]

28. Cho, K.; Mahieu, N.G.; Johnson, S.L.; Patti, G.J. After the feature presentation: Technologies bridging untargeted metabolomics and biology. Curr. Opin. Biotechnol. 2014, 28, 143-148. [CrossRef]

29. Claudino, W.M.; Goncalves, P.H.; di Leo, A.; Philip, P.A.; Sarkar, F.H. Metabolomics in cancer: A bench-to-bedside intersection. Crit. Rev. Oncol. Hematol. 2012, 84, 1-7. [CrossRef]

30. Beger, R.D. A review of applications of metabolomics in cancer. Metabolites 2013, 3, 552-574. [CrossRef]

31. Lécuyer, L.; Victor Bala, A.; Deschasaux, M.; Bouchemal, N.; Nawfal Triba, M.; Vasson, M.-P.; Rossary, A.; Demidem, A.; Galan, P.; Hercberg, S.; et al. NMR metabolomic signatures reveal predictive plasma metabolites associated with long-term risk of developing breast cancer. Int. J. Epidemiol. 2018, 47, 484-494. [CrossRef] [PubMed]

32. Gu, H.; Gowda, G.A.N.; Raftery, D. Metabolic profiling: Are we en route to better diagnostic tests for cancer? Future Oncol. 2012, 8, 1207-1210. [CrossRef]

33. Jové, M.; Collado, R.; Quiles, J.L.; Ramírez-Tortosa, M.-C.; Sol, J.; Ruiz-Sanjuan, M.; Fernandez, M.; de la Torre Cabrera, C.; Ramírez-Tortosa, C.; Granados-Principal, S.; et al. A plasma metabolomic signature discloses human breast cancer. Oncotarget 2017, 8, 19522-19533. [CrossRef]

34. Fan, Y.; Zhou, X.; Xia, T.-S.; Chen, Z.; Li, J.; Liu, Q.; Alolga, R.N.; Chen, Y.; Lai, M.-D.; Li, P.; et al. Human plasma metabolomics for identifying differential metabolites and predicting molecular subtypes of breast cancer. Oncotarget 2016, 7, 9925-9938. [CrossRef] [PubMed]

35. Bain, J.R.; Stevens, R.D.; Wenner, B.R.; Ilkayeva, O.; Muoio, D.M.; Newgard, C.B. Metabolomics Applied to Diabetes Research: Moving From Information to Knowledge. Diabetes 2009, 58, 2429-2443. [CrossRef]

36. Günther, U.L. Metabolomics Biomarkers for Breast Cancer. Pathobiology 2015, 82, 153-165. [CrossRef] [PubMed]

37. Hadi, N.I.; Jamal, Q. “OMIC” tumor markers for breast cancer: A review. Pakistan J. Med. Sci. 2015, 31, $1256-1262$.

38. Cappelletti, V.; Iorio, E.; Miodini, P.; Silvestri, M.; Dugo, M.; Daidone, M.G. Metabolic Footprints and Molecular Subtypes in Breast Cancer. Dis. Markers 2017, 2017, 1-19. [CrossRef]

39. McCartney, A.; Vignoli, A.; Biganzoli, L.; Love, R.; Tenori, L.; Luchinat, C.; Di Leo, A. Metabolomics in breast cancer: A decade in review. Cancer Treat. Rev. 2018, 67, 88-96. [CrossRef]

40. Anderson, N.M.; Mucka, P.; Kern, J.G.; Feng, H. The emerging role and targetability of the TCA cycle in cancer metabolism. Protein Cell 2018, 9, 216-237. [CrossRef]

41. Ryan, D.G.; Murphy, M.P.; Frezza, C.; Prag, H.A.; Chouchani, E.T.; O’Neill, L.A.; Mills, E.L. Coupling Krebs cycle metabolites to signalling in immunity and cancer. Nat. Metab. 2019, 1, 16-33. [CrossRef] [PubMed]

42. Ciccarone, F.; Vegliante, R.; Di Leo, L.; Ciriolo, M.R. The TCA cycle as a bridge between oncometabolism and DNA transactions in cancer. Semin. Cancer Biol. 2017, 47, 50-56. [CrossRef] [PubMed] 
43. Cífková, E.; Lísa, M.; Hrstka, R.; Vrána, D.; Gatěk, J.; Melichar, B.; Holčapek, M. Correlation of lipidomic composition of cell lines and tissues of breast cancer patients using hydrophilic interaction liquid chromatography/electrospray ionization mass spectrometry and multivariate data analysis. Rapid Commun. Mass Spectrom. 2017, 31, 253-263. [CrossRef] [PubMed]

44. Silva, C.L.; Perestrelo, R.; Silva, P.; Tomás, H.; Câmara, J.S. Volatile metabolomic signature of human breast cancer cell lines. Sci. Rep. 2017, 7, 43969. [CrossRef]

45. Le Guennec, A.; Tea, I.; Antheaume, I.; Martineau, E.; Charrier, B.; Pathan, M.; Akoka, S.; Giraudeau, P. Fast Determination of Absolute Metabolite Concentrations by Spatially Encoded 2D NMR: Application to Breast Cancer Cell Extracts. Anal. Chem. 2012, 84, 10831-10837. [CrossRef]

46. Willmann, L.; Schlimpert, M.; Hirschfeld, M.; Erbes, T.; Neubauer, H.; Stickeler, E.; Kammerer, B. Alterations of the exo- and endometabolite profiles in breast cancer cell lines: A mass spectrometry-based metabolomics approach. Anal. Chim. Acta 2016, 925, 34-42. [CrossRef]

47. Cao, Y.; Wang, Q.; Gao, P.; Dong, J.; Zhu, Z.; Fang, Y.; Fang, Z.; Sun, X.; Sun, T. A dried blood spot mass spectrometry metabolomic approach for rapid breast cancer detection. Onco. Targets. Ther. 2016, 9, 1389. [CrossRef] [PubMed]

48. Martinez-Lozano Sinues, P.; Landoni, E.; Miceli, R.; Dibari, V.F.; Dugo, M.; Agresti, R.; Tagliabue, E.; Cristoni, S.; Orlandi, R. Secondary electrospray ionization-mass spectrometry and a novel statistical bioinformatic approach identifies a cancer-related profile in exhaled breath of breast cancer patients: A pilot study. J. Breath Res. 2015, 9, 31001. [CrossRef]

49. Cala, M.P.; Aldana, J.; Medina, J.; Sánchez, J.; Guio, J.; Wist, J.; Meesters, R.J.W. Multiplatform plasma metabolic and lipid fingerprinting of breast cancer: A pilot control-case study in Colombian Hispanic women. PLoS ONE 2018, 13, e0190958. [CrossRef]

50. Roig, B.; Rodríguez-Balada, M.; Samino, S.; Lam, E.W.-F.; Guaita-Esteruelas, S.; Gomes, A.R.; Correig, X.; Borràs, J.; Yanes, O.; Gumà, J. Metabolomics reveals novel blood plasma biomarkers associated to the BRCA1-mutated phenotype of human breast cancer. Sci. Rep. 2017, 7, 17831. [CrossRef]

51. Cavaco, C.; Pereira, J.A.M.; Taunk, K.; Taware, R.; Rapole, S.; Nagarajaram, H.; Câmara, J.S. Screening of salivary volatiles for putative breast cancer discrimination: An exploratory study involving geographically distant populations. Anal. Bioanal. Chem. 2018, 410, 1-10. [CrossRef] [PubMed]

52. Tsutsui, H.; Mochizuki, T.; Inoue, K.; Toyama, T.; Yoshimoto, N.; Endo, Y.; Todoroki, K.; Min, J.Z.; Toyo'oka, T. High-Throughput LC-MS/MS Based Simultaneous Determination of Polyamines Including N-Acetylated Forms in Human Saliva and the Diagnostic Approach to Breast Cancer Patients. Anal. Chem. 2013, 85, 11835-11842. [CrossRef] [PubMed]

53. Zhong, L.; Cheng, F.; Lu, X.; Duan, Y.; Wang, X. Untargeted saliva metabonomics study of breast cancer based on ultra performance liquid chromatography coupled to mass spectrometry with HILIC and RPLC separations. Talanta 2016, 158, 351-360. [CrossRef]

54. Takayama, T.; Tsutsui, H.; Shimizu, I.; Toyama, T.; Yoshimoto, N.; Endo, Y.; Inoue, K.; Todoroki, K.; Min, J.Z.; Mizuno, H.; et al. Diagnostic approach to breast cancer patients based on target metabolomics in saliva by liquid chromatography with tandem mass spectrometry. Clin. Chim. Acta 2016, 452, 18-26. [CrossRef] [PubMed]

55. Cífková, E.; Holčapek, M.; Lísa, M.; Vrána, D.; Gatěk, J.; Melichar, B. Determination of lipidomic differences between human breast cancer and surrounding normal tissues using HILIC-HPLC/ESI-MS and multivariate data analysis. Anal. Bioanal. Chem. 2015, 407, 991-1002. [CrossRef] [PubMed]

56. Budhu, A.; Terunuma, A.; Zhang, G.; Hussain, S.P.; Ambs, S.; Wang, X.W. Metabolic profiles are principally different between cancers of the liver, pancreas and breast. Int. J. Biol. Sci. 2014, 10, 966-972. [CrossRef] [PubMed]

57. Kanaan, Y.M.; Sampey, B.P.; Beyene, D.; Esnakula, A.K.; Naab, T.J.; Ricks-Santi, L.J.; Dasi, S.; Day, A.; Blackman, K.W.; Frederick, W.; et al. Metabolic profile of triple-negative breast cancer in African-American women reveals potential biomarkers of aggressive disease. Cancer Genom. Proteom. 2014, 11, $279-294$.

58. Tenori, L.; Oakman, C.; Morris, P.G.; Gralka, E.; Turner, N.; Cappadona, S.; Fornier, M.; Hudis, C.; Norton, L.; Luchinat, C.; et al. Serum metabolomic profiles evaluated after surgery may identify patients with oestrogen receptor negative early breast cancer at increased risk of disease recurrence. Results from a retrospective study. Mol. Oncol. 2015, 9, 128-139. [CrossRef] 
59. Porto-Figueira, P.; Pereira, J.A.M.; Câmara, J.S. Exploring the potential of needle trap microextraction combined with chromatographic and statistical data to discriminate different types of cancer based on urinary volatomic biosignature. Anal. Chim. Acta 2018, 1023, 53-63. [CrossRef]

60. Thomson, C.A.; Thompson, P.A. Dietary patterns, risk and prognosis of breast cancer. Futur. Oncol. 2009, 5, 1257-1269. [CrossRef]

61. Martineau, E.; Tea, I.; Akoka, S.; Giraudeau, P. Absolute quantification of metabolites in breast cancer cell extracts by quantitative 2D 1H INADEQUATE NMR. NMR Biomed. 2012, 25, 985-992. [CrossRef]

62. Kim, K.-J.; Kim, H.-J.; Park, H.-G.; Hwang, C.-H.; Sung, C.; Jang, K.-S.; Park, S.-H.; Kim, B.-G.; Lee, Y.-K.; Yang, Y.-H.; et al. A MALDI-MS-based quantitative analytical method for endogenous estrone in human breast cancer cells. Sci. Rep. 2016, 6, 24489. [CrossRef] [PubMed]

63. Singh, A.; Sharma, R.K.; Chagtoo, M.; Agarwal, G.; George, N.; Sinha, N.; Godbole, M.M. 1H NMR Metabolomics Reveals Association of High Expression of Inositol 1, 4, 5 Trisphosphate Receptor and Metabolites in Breast Cancer Patients. PLoS ONE 2017, 12, e0169330. [CrossRef] [PubMed]

64. Zhao, C.; Xie, P.; Wang, H.; Cai, Z. Liquid chromatography-mass spectrometry-based metabolomics and lipidomics reveal toxicological mechanisms of bisphenol F in breast cancer xenografts. J. Hazard. Mater. 2018. [CrossRef]

65. Huang, S.; Chong, N.; Lewis, N.E.; Jia, W.; Xie, G.; Garmire, L.X. Novel personalized pathway-based metabolomics models reveal key metabolic pathways for breast cancer diagnosis. Genome Med. 2016, 8, 34. [CrossRef] [PubMed]

66. Dougan, M.M.; Li, Y.; Chu, L.W.; Haile, R.W.; Whittemore, A.S.; Han, S.S.; Moore, S.C.; Sampson, J.N.; Andrulis, I.L.; John, E.M.; et al. Metabolomic profiles in breast cancer: A pilot case-control study in the breast cancer family registry. BMC Cancer 2018, 18, 532. [CrossRef]

67. Gu, H.; Pan, Z.; Xi, B.; Asiago, V.; Musselman, B.; Raftery, D. Principal component directed partial least squares analysis for combining nuclear magnetic resonance and mass spectrometry data in metabolomics: Application to the detection of breast cancer. Anal. Chim. Acta 2011, 686, 57-63. [CrossRef] [PubMed]

68. Jobard, E.; Pontoizeau, C.; Blaise, B.J.; Bachelot, T.; Elena-Herrmann, B.; Trédan, O. A serum nuclear magnetic resonance-based metabolomic signature of advanced metastatic human breast cancer. Cancer Lett. 2014, 343, $33-41$. [CrossRef] [PubMed]

69. Lv, W.; Yang, T. Identification of possible biomarkers for breast cancer from free fatty acid profiles determined by GC-MS and multivariate statistical analysis. Clin. Biochem. 2012, 45, 127-133. [CrossRef]

70. Lyon, D.E.; Starkweather, A.; Yao, Y.; Garrett, T.; Kelly, D.L.; Menzies, V.; Dereziński Pawełand Datta, S.; Kumar, S.; Jackson-Cook, C. Pilot Study of Metabolomics and Psychoneurological Symptoms in Women With Early Stage Breast Cancer. Biol. Res. Nurs. 2018, 20, 227-236. [CrossRef]

71. Wei, S.; Liu, L.; Zhang, J.; Bowers, J.; Gowda, G.A.N.; Seeger, H.; Fehm, T.; Neubauer, H.J.; Vogel, U.; Clare, S.E.; et al. Metabolomics approach for predicting response to neoadjuvant chemotherapy for breast cancer. Mol. Oncol. 2013, 7, 297-307. [CrossRef]

72. Playdon, M.C.; Ziegler, R.G.; Sampson, J.N.; Stolzenberg-Solomon, R.; Thompson, H.J.; Irwin, M.L.; Mayne, S.T.; Hoover, R.N.; Moore, S.C. Nutritional metabolomics and breast cancer risk in a prospective study. Am. J. Clin. Nutr. 2017, 106, 637-649. [CrossRef] [PubMed]

73. Cala, M.; Aldana, J.; Sánchez, J.; Guio, J.; Meesters, R.J.W. Urinary metabolite and lipid alterations in Colombian Hispanic women with breast cancer: A pilot study. J. Pharm. Biomed. Anal. 2018, 152, $234-241$. [CrossRef] [PubMed]

74. Tayyari, F.; Gowda, G.A.N.; Olopade, O.F.; Berg, R.; Yang, H.H.; Lee, M.P.; Ngwa, W.F.; Mittal, S.K.; Raftery, D.; Mohammed, S.I. Metabolic profiles of triple-negative and luminal A breast cancer subtypes in African-American identify key metabolic differences. Oncotarget 2018, 9, 11677-11690. [CrossRef]

75. Bathen, T.F.; Geurts, B.; Sitter, B.; Fjøsne, H.E.; Lundgren, S.; Buydens, L.M.; Gribbestad, I.S.; Postma, G.; Giskeødegård, G.F. Feasibility of MR Metabolomics for Immediate Analysis of Resection Margins during Breast Cancer Surgery. PLoS ONE 2013, 8, e61578. [CrossRef] [PubMed]

76. Tang, X.; Lin, C.-C.; Spasojevic, I.; Iversen, E.S.; Chi, J.-T.; Marks, J.R. A joint analysis of metabolomics and genetics of breast cancer. Breast Cancer Res. 2014, 16, 415. [CrossRef]

77. Budczies, J.; Pfitzner, B.M.; Györffy, B.; Winzer, K.-J.; Radke, C.; Dietel, M.; Fiehn, O.; Denkert, C. Glutamate enrichment as new diagnostic opportunity in breast cancer. Int. J. Cancer 2015, 136, 1619-1628. [CrossRef] 
78. Vettukattil, R.; Hetland, T.E.; Flørenes, V.A.; Kærn, J.; Davidson, B.; Bathen, T.F. Proton magnetic resonance metabolomic characterization of ovarian serous carcinoma effusions: chemotherapy-related effects and comparison with malignant mesothelioma and breast carcinoma. Hum. Pathol. 2013, 44, 1859-1866. [CrossRef]

79. Euceda, L.R.; Haukaas, T.H.; Giskeødegård, G.F.; Vettukattil, R.; Engel, J.; Silwal-Pandit, L.; Lundgren, S.; Borgen, E.; Garred, Ø.; Postma, G.; et al. Evaluation of metabolomic changes during neoadjuvant chemotherapy combined with bevacizumab in breast cancer using MR spectroscopy. Metabolomics 2017, 13, 37. [CrossRef]

80. Gogiashvili, M.; Horsch, S.; Marchan, R.; Gianmoena, K.; Cadenas, C.; Tanner, B.; Naumann, S.; Ersova, D.; Lippek, F.; Rahnenführer, J.; et al. Impact of intratumoral heterogeneity of breast cancer tissue on quantitative metabolomics using high-resolution magic angle spinning 1H NMR spectroscopy. NMR Biomed. 2018, 31, e3862. [CrossRef]

81. Choi, J.S.; Baek, H.-M.; Kim, S.; Kim, M.J.; Youk, J.H.; Moon, H.J.; Kim, E.-K.; Nam, Y.K. Magnetic resonance metabolic profiling of breast cancer tissue obtained with core needle biopsy for predicting pathologic response to neoadjuvant chemotherapy. PLoS ONE 2013, 8, e83866. [CrossRef]

82. Budczies, J.; Brockmöller, S.F.; Müller, B.M.; Barupal, D.K.; Richter-Ehrenstein, C.; Kleine-Tebbe, A.; Griffin, J.L.; Orešič, M.; Dietel, M.; Denkert, C.; et al. Comparative metabolomics of estrogen receptor positive and estrogen receptor negative breast cancer: alterations in glutamine and beta-alanine metabolism. J. Proteomics 2013, 94, 279-288. [CrossRef]

83. Dai, C.; Arceo, J.; Arnold, J.; Sreekumar, A.; Dovichi, N.J.; Li, J.; Littlepage, L.E. Metabolomics of oncogene-specific metabolic reprogramming during breast cancer. Cancer Metab. 2018, 6, 5. [CrossRef]

84. Yu, L.; Jiang, C.; Huang, S.; Gong, X.; Wang, S.; Shen, P. Analysis of urinary metabolites for breast cancer patients receiving chemotherapy by CE-MS coupled with on-line concentration. Clin. Biochem. 2013, 46, 1065-1073. [CrossRef] [PubMed]

85. Krilaviciute, A.; Heiss, J.A.; Leja, M.; Kupcinskas, J.; Haick, H.; Brenner, H. Detection of cancer through exhaled breath: A systematic review. Oncotarget 2015, 6, 38643-38657. [CrossRef] [PubMed]

86. Zhang, A.; Sun, H.; Wang, P.; Han, Y.; Wang, X. Modern analytical techniques in metabolomics analysis. Analyst 2012, 137, 293-300. [CrossRef]

87. Issaq, H.J.; Van, Q.N.; Waybright, T.J.; Muschik, G.M.; Veenstra, T.D. Analytical and statistical approaches to metabolomics research. J. Sep. Sci. 2009, 32, 2183-2199. [CrossRef] [PubMed]

88. Dunn, W.B.; Bailey, N.J.C.; Johnson, H.E. Measuring the metabolome: Current analytical technologies. Analyst 2005, 130, 606. [CrossRef] [PubMed]

89. Wang, J.H.; Byun, J.; Pennathur, S. Analytical approaches to metabolomics and applications to systems biology. Semin. Nephrol. 2010, 30, 500-511. [CrossRef]

90. Sas, K.M.; Karnovsky, A.; Michailidis, G.; Pennathur, S. Metabolomics and diabetes: Analytical and computational approaches. Diabetes 2015, 64, 718-732. [CrossRef] [PubMed]

91. Ahad, T.; Jasia Nissar, I.; Tehmeena Ahad, C.; Nissar, J. Division of food science and technology, Skuast-k Fingerprinting in determining the adultration of food. J. Pharmacogn. Phytochem. JPP 2017, 6, 1543-1553.

92. Narwate, B.M.; Ghule, P.J.; Ghule, A.V.; Darandale, A.S.; Wagh, J.G. Ultra performance liquid chromatography: A new revolution in liquid chromatography. Int. J. Pharm. Drug Anal. 2014, 2.

93. Yandamuri, N.; Srinivas Nagabattula, K.R.; Swamy Kurra, S.; Batthula, S.; S Nainesha Allada, L.P.; Bandam, P. Comparative Study of New Trends in HPLC: A Review. Int. J. Pharm. Sci. Rev. Res. 2013, 23, 52-57.

94. De Vos, J.; Broeckhoven, K.; Eeltink, S. Advances in Ultrahigh-Pressure Liquid Chromatography Technology and System Design. Anal. Chem. 2016, 88, 262-278. [CrossRef]

95. Cacciola, F.; Farnetti, S.; Dugo, P.; Marriott, P.J.; Mondello, L. Comprehensive two-dimensional liquid chromatography for polyphenol analysis in foodstuffs. J. Sep. Sci. 2017, 40, 7-24. [CrossRef]

96. Reichenbach, S.E.; Tian, X.; Tao, Q.; Ledford, E.B.; Wu, Z.; Fiehn, O. Informatics for cross-sample analysis with comprehensive two-dimensional gas chromatography and high-resolution mass spectrometry (GCxGC-HRMS). Talanta 2011, 83, 1279-1288. [CrossRef] [PubMed]

97. Yu, Z.; Huang, H.; Reim, A.; Charles, P.D.; Northage, A.; Jackson, D.; Parry, I.; Kessler, B.M. Optimizing 2D gas chromatography mass spectrometry for robust tissue, serum and urine metabolite profiling. Talanta 2017, 165, 685-691. [CrossRef] [PubMed]

98. Umar, A.; Luider, T.M.; Foekens, J.A.; Paša-Tolić, L. NanoLC-FT-ICR MS improves proteome coverage attainable for $\sim 3000$ laser-microdissected breast carcinoma cells. Proteomics 2007, 7, 323-329. [CrossRef] 
99. Hendriks, M.M.W.B.; van Eeuwijk, F.A.; Jellema, R.H.; Westerhuis, J.A.; Reijmers, T.H.; Hoefsloot, H.C.J.; Smilde, A.K. Data-processing strategies for metabolomics studies. TrAC Trends Anal. Chem. 2011, 30, 1685-1698. [CrossRef]

100. Yi, L.; Dong, N.; Yun, Y.; Deng, B.; Ren, D.; Liu, S.; Liang, Y. Chemometric methods in data processing of mass spectrometry-based metabolomics: A review. Anal. Chim. Acta 2016, 914, 17-34. [CrossRef]

101. Gromski, P.S.; Muhamadali, H.; Ellis, D.I.; Xu, Y.; Correa, E.; Turner, M.L.; Goodacre, R. A tutorial review: Metabolomics and partial least squares-discriminant analysis-A marriage of convenience or a shotgun wedding. Anal. Chim. Acta 2015, 879, 10-23. [CrossRef]

102. Sugimoto, M.; Wong, D.T.; Hirayama, A.; Soga, T.; Tomita, M. Capillary electrophoresis mass spectrometry-based saliva metabolomics identified oral, breast and pancreatic cancer-specific profiles. Metabolomics 2010, 6, 78-95. [CrossRef] [PubMed]

103. van den Berg, R.A.; Hoefsloot, H.C.; Westerhuis, J.A.; Smilde, A.K.; van der Werf, M.J. Centering, scaling, and transformations: Improving the biological information content of metabolomics data. BMC Genom. 2006, 7, 142. [CrossRef]

104. Sysi-Aho, M.; Katajamaa, M.; Yetukuri, L.; Orešič, M. Normalization method for metabolomics data using optimal selection of multiple internal standards. BMC Bioinform. 2007, 8, 93. [CrossRef] [PubMed]

105. Kohl, S.M.; Klein, M.S.; Hochrein, J.; Oefner, P.J.; Spang, R.; Gronwald, W. State-of-the art data normalization methods improve NMR-based metabolomic analysis. Metabolomics 2012, 8, 146-160. [CrossRef] [PubMed]

106. Xi, B.; Gu, H.; Baniasadi, H.; Raftery, D. Statistical analysis and modeling of mass spectrometry-based metabolomics data. Methods Mol. Biol. 2014, 1198, 333-353.

107. Zhang, A.; Sun, H.; Qiu, S.; Wang, X. Metabolomics in noninvasive breast cancer. Clin. Chim. Acta 2013, 424, 3-7. [CrossRef]

108. Xia, J.; Broadhurst, D.I.; Wilson, M.; Wishart, D.S. Translational biomarker discovery in clinical metabolomics: An introductory tutorial. Metabolomics 2013, 9, 280-299. [CrossRef]

109. Liland, K.H. Multivariate methods in metabolomics-From pre-processing to dimension reduction and statistical analysis. TrAC Trends Anal. Chem. 2011, 30, 827-841. [CrossRef]

110. Köhn, H.-F.; Hubert, L.J. Hierarchical Cluster Analysis. In Wiley StatsRef: Statistics Reference Online; John Wiley \& Sons, Ltd.: Chichester, UK, 2015; pp. 1-13.

111. Jain, A.K. Data clustering: 50 years beyond K-means. Pattern Recognit. Lett. 2010, 31, 651-666. [CrossRef]

112. Sperandei, S. Understanding logistic regression analysis. Biochem. Med. 2014, 24, 12-18. [CrossRef] [PubMed]

113. Ivanescu, A.E.; Li, P.; George, B.; Brown, A.W.; Keith, S.W.; Raju, D.; Allison, D.B. The importance of prediction model validation and assessment in obesity and nutrition research. Int. J. Obes. 2016, 40, 887-894. [CrossRef] [PubMed]

114. Xu, Q.-S.; Liang, Y.-Z.; Du, Y.-P. Monte Carlo cross-validation for selecting a model and estimating the prediction error in multivariate calibration. J. Chemom. 2004, 18, 112-120. [CrossRef]

115. Haddad, K.; Rahman, A.; A Zaman, M.; Shrestha, S. Applicability of Monte Carlo cross validation technique for model development and validation using generalised least squares regression. J. Hydrol. 2013, 482, 119-128. [CrossRef]

116. Jaki, T.; Su, T.-L.; Kim, M.; Van Horn, M.L. An evaluation of the bootstrap for model validation in mixture models. Commun. Stat. -Simul. Comput. 2018, 47, 1028-1038. [CrossRef] [PubMed]

117. Lindgren, F.; Hansen, B.; Karcher, W.; Sjöström, M.; Eriksson, L. Model Validation by Permutation tests: Applications to VariableSselection. J. Chemom. 1996, 10, 521-532. [CrossRef]

(C) 2019 by the authors. Licensee MDPI, Basel, Switzerland. This article is an open access article distributed under the terms and conditions of the Creative Commons Attribution (CC BY) license (http://creativecommons.org/licenses/by/4.0/). 